\title{
Trial Incentives in Sequential Litigation
}

\author{
Dan Bernhardt and Frances Zhiyun $\mathrm{Xu}^{*}$
}

May 2, 2012

\begin{abstract}
We analyze when and why trials can emerge in equilibrium when a defendant may sequentially face multiple plaintiffs. Subsequent potential plaintiffs learn about their chances of winning from the initial trial outcome. A trial in the initial case is like an experiment that the defendant can run that would induce plaintiffs' learning. We show that the initial case can go to trial in equilibrium when a favorable trial outcome for the defense can deter potential future plaintiffs from filing lawsuits. The possibility of meritless lawsuits further raises the attraction of trials. We also show that when the initial plaintiff's attorney may represent future clients, trials are more likely both because the attorney gains from learning, and because his ability to attract future clients may depend on how much his initial client receives.
\end{abstract}

Keywords: Trial, Settlement, Learning, Sequential Litigation.

${ }^{*}$ We are grateful for helpful comments from Andrew Daughety, Jennifer Reinganum, Wing Suen and Yuk-fai Fong. All errors are our own. Dan Bernhardt: University of Illinois, Champaign, Illinois 61820, danber@uiuc.edu. Frances Xu: University of Hong Kong, Pok Fu Lam, Hong Kong, zfxu@hku.hk. 


\section{Introduction}

When and why do litigating parties go to trial? Given the high costs associated with trials, it would seem to be in the mutual interest of a plaintiff and defendant to reach a settlement that obviates the need for a trial that seems to destroy so much surplus. Researchers have offered many explanations for why the litigating parties fail to settle and go to trial despite the large potential cost savings, including prediction mistakes, asymmetric information and multiple-litigant externalities. ${ }^{1}$

In this paper we analyze when and why trials can emerge in equilibrium in a setting where a defendant may sequentially face multiple plaintiffs. Such sequential litigation arises in many scenarios, including product liability, personal injury, environmental pollution and so on, where multiple plaintiffs may have been injured by the same defendant, and they become aware of the damage, or become capable of filing lawsuits, at different points in time. ${ }^{2}$

Sequential litigation has several distinctive features that are important to integrate and understand. First, if an initial case goes to trial, future potential litigating parties will use the trial outcome-whether the defendant wins or loses, and possibly how much the initial plaintiff receives - to update about the likely outcomes if their cases go to trial. That is, there is plaintiff learning. They can learn because the trial outcomes of the initial lawsuit and subsequent ones are positively correlated, and trials convey more information than do settlements. This positive correlation emerges naturally in sequential litigation for many reasons-courts may follow precedents established in the initial trial, and potential plaintiffs may learn about a defendant's culpability or vulnerability, or about which legal strategies work.

The defendant understands how plaintiff's learning makes outcomes in the initial case affect the future costs and settlement amounts in subsequent possible lawsuits. When deciding whether to settle or go to trial, a defendant internalizes the effects of a trial on (a) future decisions by possible plaintiffs to file lawsuits, (b) future settlement outcomes, and (c) future trial outcomes. Going to trial represents a gamble not only over current payouts, but also over the future numbers of plaintiffs, levels of future settlements and future legal costs - and the question becomes when does a defendant have an incentive to take this complex trial gamble rather than settle?

In sequential litigation, one must also distinguish between pre-trial costs and trial costs. Trial costs can be avoided by settling a case, while pre-trial costs must be incurred even prior to any settlement. In practice, most litigation expenses involve discovery and experts, and are incurred prior

\footnotetext{
${ }^{1}$ We will review the literature in detail later in the introduction.

${ }^{2}$ See e.g., Rosenberg (2002) or Che and Yi (1993) for examples of sequential lawsuits.
} 
to a trial. ${ }^{3}$ For example, most of an expert's time is devoted to his or her review of case materials, report preparation and pre-trial deposition. These discovery and expert costs far outweigh the trial costs that can be avoided by a settlement. When there is only a single plaintiff_-in a "one-off" case that has no bearing on other cases-pre-trial costs are, in effect, sunk costs that have no impact on strategic decisions, and hence can be ignored by a researcher since only potential trial costs enter settlements. This ceases to be true in sequential litigation. Now, the potential pre-trial costs of future litigation enter a defendant's decision-making, and hence the attraction of settling the first case or taking it to trial.

In sequential litigation, one should also account for the prospective impact of meritless cases, i.e., of cases that have a surface appearance of those with merit, but whose lack of merit would be revealed at trial. Initial trial outcomes serve to spread beliefs about the prospects of serious cases in the future, and this feeds back to affect how many meritless cases a defendant may have to confront.

Further, in sequential litigation, not only may a defendant care about the future ramifications of the initial trial outcome, but so may the plaintiff's attorney. In particular, while the initial plaintiff does not care about future cases, his attorney might. First, information revealed by an initial trial outcome may help the plaintiff's attorney make more informed decisions about whether to file on behalf of future clients. Second, it is often difficult for potential future plaintiffs to assess whether a particular lawyer will do a good or bad job for his clients. As a result, potential plaintiffs may rely on the payment received by the initial plaintiff to assess the quality of his attorney. If the initial plaintiff's lawyer extracts a larger settlement, or wins a greater payment at trial, then he or she may attract more future clients. Advertisements by lawyers highlighting the size of settlements and trial awards won by their clients indicate that potential plaintiffs weigh them heavily in their choices of legal representation. This third-party audience composed of potential future clients can raise the settlement required to induce an initial plaintiff's lawyer to forgo a trial.

We build a simple two-period model of sequential litigation to get at these issues. The first period corresponds to the first date at which a plaintiff realizes that he has a case against the defendant that has sufficient merit to make filing a lawsuit worthwhile (i.e., the expected payment to the plaintiff covers any pre-trial and trial costs that might be incurred). There is no asymmetric information between the defendant and the plaintiff: they share the same prior belief about their prospects. The second period telescopes into a single period all future cases whose trial outcomes may be correlated with that of the initial case. To make the analysis transparent, we assume that the payment the defendant must make to a plaintiff who wins at trial is known: the sole source of

\footnotetext{
${ }^{3}$ Final Colorado Civil Access Pilot Project Overview 8-31-11, Website of the Colorado Supreme Court.
} 
uncertainty concerns whether a plaintiff would win a trial. To highlight how learning by potential future plaintiffs can lead to trials, we first assume away both meritless lawsuits and any stake the initial plaintiff's attorney has in future cases. That is, we consider incentives to go to trial that devolve solely from the positive correlation in trial outcomes, so that potential plaintiffs update positively about their chances if the defendant loses the initial trial, but update negatively if the defendant wins. To ease presentation, we initially assume that the defendant has all bargaining power: the defendant can make take-it-or-leave-it offers to plaintiffs.

We identify conditions under which such learning leads to trials. We first prove that once learning has occurred (i.e., after the initial lawsuit), then all cases are settled in order to avoid trial costs and thereby maximize the surplus that a plaintiff and defendant divide. We then prove that for the initial lawsuit to go to trial, (a) an initial win by the defense must cause future potential plaintiffs to update sufficiently negatively about their prospects that they do not file lawsuits, (b) an initial settlement, which does not alter beliefs of future plaintiffs, must not deter future potential plaintiffs, and (c) the savings from deterring future lawsuits for the defendant must exceed the combined initial trial costs of the plaintiff and defendant. These conditions highlight how the central features of sequential litigation lead to trials: condition (a) is easier to satisfy when future outcomes are more closely tied to the outcome of the initial trial—with a stronger desire of a court to follow precedents or a greater similarity among plaintiffs, there is a greater reduction in the winning probability a plaintiff expects in a future trial following an initial win by the defense; and condition (c) becomes easy to satisfy when there are many possible future cases, so that the savings from deterring future lawsuits are larger for the defendant.

We then observe that while the conditions under which a trial occurs are quite plausible, they are also demanding. In particular, the payment to a winning plaintiff cannot be so high that even a plaintiff-loss in the initial trial fails to deter subsequent plaintiffs from filing lawsuits; but the payment to a winning plaintiff cannot be so low that an initial settlement would deter subsequent plaintiffs from filing. Of course, the fact that it was worthwhile for the initial plaintiff to file suggests that the expected payment is high enough, as subsequent plaintiffs likely face lower costs. Finally, even if these two conditions are satisfied, it still might not be in the interest of the defendant to take the first case trial- the gains from possibly deterring future lawsuits must exceed the initial trial costs. In particular, there must be substantial savings in pre-trial costs associated with future litigation for the initial trial even to be able to reduce the expected payout in future litigation: otherwise, a Jensen's Inequality type of argument implies that giving future plaintiffs more information 
to self-select on entering or not raises expected future settlement payments, hurting the defendant. ${ }^{4}$

We next introduce the possibility of meritless lawsuits - cases that have no chance of winning in a trial, but, due to their similar appearances to legitimate cases, may be settled by a defendant. We identify two ways in which the possibility of future meritless cases increases the circumstances under which a defendant takes the initial case to trial. First, a trial that deters future plaintiffs with serious cases also deters plaintiffs with meritless cases. Second, even when a trial does not deter future serious cases from being filed, it can still reduce the expected payout in future meritless cases: information revealed by the initial trial helps the defendant because her expected payout to meritless cases is a concave function of the probability that a future plaintiff with a serious case will win. Most clearly, with a large pool of possible future meritless cases, to deter meritless lawsuits, a defendant adopts a mixed strategy of sometimes going to trial in the future, and, to preserve the defendant's indifference, fewer meritless cases must be filed when legitimate cases are stronger.

The conditions under which the initial case goes to trial, when motivated by the desire to deter future plaintiffs, are qualitatively the same regardless of whether legal decisions are made by the plaintiff, or by his attorney, or when a plaintiff has greater bargaining power and can extract a greater settlement. We then consider how outcomes are affected if the initial plaintiff's attorney also has a stake in future trials because she may represent future plaintiffs. We show that this increases the circumstances under which the initial case goes to trial: the plaintiff's attorney prefers a trial because it provides information that allows him to fine tune future entry decisions.

In each of the scenarios above, for the initial case to go to trial, it is crucial that likely trial outcomes be positively correlated-trials are driven by learning about the chances that a plaintiff will win a trial. We then assume away this correlation to show how another form of intertemporal linkage can lead the initial case to go to trial. In particular, future potential plaintiffs may rely on the payment received by the initial plaintiff to assess his attorney's ability, and hence whether to hire him. Thus, future plaintiffs are more likely to use the initial plaintiff's lawyer if he extracts a larger settlement, or wins a greater payment at trial. While a defendant does not care about which attorneys represent future plaintiffs, the initial plaintiff's lawyer does, and this can raise the amount a defendant must pay to settle. The defendant and plaintiff's lawyer may decide to take the initial case to trial because the increased surplus that they extract at the expense of potential rival plaintiff lawyers may more than cover the initial case's trial costs. We characterize the conditions under which the initial litigation goes to trial. In particular, the initial trial stakes cannot be so high that the correspondingly larger settlement offer allows the initial plaintiff's attorney to attract (enough)

\footnotetext{
${ }^{4}$ If a plaintiff has enough bargaining power, trials can emerge even when his pre-trial costs are zero.
} 
future clients; and the value of future clients that can be gained through a plaintiff-win must be large enough to cover the trial costs.

The Literature. Researchers have identified other reasons for why litigating parties can fail to settle. ${ }^{5}$ For example, trials can result when the litigating parties have different priors and some are overly-optimistic (Gross and Syverud 1991, Hay and Spier 1998, Daughety 2000, or Daughety and Reinganum 2005). This source of trials is absent in our model because the litigating parties share a common prior about the likelihood of a defendant-win. Trials can also emerge if one litigating party has private information (Reinganum and Wilde 1986 build a signaling model where the informed party makes a settlement offer; Bebchuk 1986 and Spier 1992 build screening models where the informed party receives a settlement offer). Several papers explore trial/settlement incentives in sequential litigation with multiple plaintiffs when one party is privately informed. Briggs et al. (1996) considers a privately-informed defendant, showing that the existence of subsequent cases increases a guilty defendant's incentive to pool with non-guilty types. This causes the initial plaintiff to reject settlement offers more often, so more cases go to trial. In Che and Yi (1993), cases are connected by the court's practice of following precedent. In their model, a defendant makes screening offers to privately-informed plaintiffs and the defendant has an incentive to set a precedent via trial. Yang (1996) considers privately-informed plaintiffs, where with correlation in plaintiff type, an uninformed defendant may want to learn about future plaintiffs via an initial trial.

In contrast to this literature, in most of our analysis, the defendant and plaintiffs share the same information-our focus is on identifying the conditions under which a defendant wants to experiment by going to trial in order to induce common learning by all parties. When we introduce meritless cases, future plaintiffs have private information about whether their cases have merit; here, we show that when the initial plaintiff and defendant are symmetrically informed, this further enhances a defendant's incentives to induce common learning by taking the first case to trial.

Papers showing how externalities between multiple litigating parties on the same side of the bargaining can lead to trials include Kornhauser and Revesz (1994a, b), who consider two defendants facing one plaintiff, where the defendants share liabilities due to joint and several liability, and Spier (2002), who considers two plaintiffs facing one defendant, where a defendant-loss may result in bankruptcy. Meurer (1992) and Sykes (1994) show how liability insurance can lead to trials; and Spier and Sykes (1998) show how a corporate defendant's debt can do so. All of these sources for trials are absent in our model.

Cases may also be connected in ways other than a positive correlation in trial outcomes. Daugh-

\footnotetext{
${ }^{5}$ See Hay and Spier (1998), Daughety (2000), or Daughety and Reinganum (2005) for detailed reviews.
} 
ety and Reinganum (1999) and Daughety and Reinganum (2002) study settlement incentives in sequential litigation when a plaintiff can specify whether a settlement is confidential and a defendant has private information about the probability of winning. They show that a defendant and an earlier plaintiff have incentives to make their litigation confidential in order to reduce awareness of the injury by future plaintiffs. Daughety and Reinganum (2011) investigate the connections that form when later plaintiffs can join the initial plaintiff to reduce their trial costs, showing that a defendant may want to preempt later entry by settling with the initial plaintiff. ${ }^{6}$ Cases may also be connected by a "Most-Favored-Nation" clause, which entitles plaintiffs who settle early to retroactive increases in their settlements should the defendant settle with subsequent plaintiffs at better terms (Spier 2003a, 2003b, and Daughety and Reinganum 2004). Hua and Spier (2005) study a single plaintiff who might face multiple defendants, exploring how future defendants can learn from earlier litigation and exercise precaution outside of litigation when dealing with the same plaintiff.

Our paper is organized as follows. Section 2 develops our base model and analyzes several variations, exploring when a defendant can gain from trial due to the learning by subsequent potential plaintiffs about the likelihood of success. Section 3 introduces meritless cases. Section 4 establishes the robustness of our findings to alternative settlement bargaining protocols. Section 5 concludes. All proofs are in an appendix.

\section{Base Model}

Our two-date model features a single defendant $D$ who faces a sequence of potential plaintiffs who may have been damaged by $D$. All parties-defendant, plaintiffs and lawyers-are risk neutral, and there is no discounting. Date 1 of our model corresponds to the moment at which the first plaintiff, $P_{1}$, realizes that he has been injured, and that the expected reward from a lawsuit may be sufficient to compensate for the costs of pursuing the lawsuit. We collapse the arrival of all subsequent potential plaintiffs, whose trial outcomes or settlements may hinge on the outcome of the initial case, into date 2. Specifically, at date 2, independently of date-1 litigation outcomes, $N_{2}$ potential plaintiffs realize that they also have been injured. ${ }^{7}$ Our primary focus is on a defendant's interaction with the very first plaintiff, and our qualitative findings would not change if the further litigations arrive sequentially, although the analysis becomes more tedious. We describe future

\footnotetext{
${ }^{6}$ Che and Spier (2007) show how such economies of scale create negative externalities between multiple plaintiffs, which allows a defendant to use a divide-and-conquer strategy to settle with the plaintiffs for less. Trials do not happen due to symmetric information.

${ }^{7}$ In contrast, Daughety and Reinganum (2002) investigate the role of a trial to create awareness, where an injured party's probability of realizing that he is injured depends on the previous litigation outcomes.
} 
plaintiffs as "potential" because each injured party may choose not to bring a lawsuit against $D$, if the costs outweigh the expected benefits. We refer to the defendant as "she" and each plaintiff as "he", and use $P_{2}$ to describe a representative date-2 plaintiff.

As in Spier (2002), we build all relevant uncertainty into the probability that a plaintiff wins. Thus, trial outcomes are binary, either a plaintiff-win or a defendant-win. A date-t plaintiff who wins at trial receives $m_{t}>0$, where we allow the possibility that $m_{1} \neq m_{2}$. The probability that any given plaintiff wins at trial is $\pi \in[0,1]$. However, trial outcomes are positively correlated, with correlation coefficient $\rho \in(0,1)$. Consequently, if the initial case goes to trial, the verdict provides subsequent plaintiffs information about their chances. Following a date-1 plaintiff-win, a date-2 plaintiff updates to believe that he will win with probability $\bar{\pi}=\pi+\rho(1-\pi)$; and following a date-1 plaintiff-loss, a date- 2 plaintiff updates negatively to believe that he will win with only probability $\underline{\pi}=(1-\rho) \pi$. When trial outcomes are perfectly correlated, $\bar{\pi}=1$ and $\underline{\pi}=0$, and when trial outcomes are independent, $\bar{\pi}=\underline{\pi}=\pi$. The positive correlation in trial outcomes emerges naturally in sequential litigation for many reasons-courts may follow precedents established in the initial trial, and the culpability or vulnerability of the defendant are similar across cases, or the characteristic of the plaintiffs are similar as well. As a result, this positive correlation is often high.

If a plaintiff files a case, then it either (a) is settled out of court with the plaintiff accepting the defendant's take-it-or-leave-it settlement offer, (b) is withdrawn by the plaintiff, or (c) goes to trial. ${ }^{8}$ A plaintiff's net payoff is zero if he does not file, and it is any payment from the defendant less his litigation costs if he files. Litigation costs include costs of expert witness, discovery, motions and hearings. A defendant's costs may also include bad publicity. In practice, litigation costs are incurred on a continuous basis and the timing of a settlement is itself endogenous. To simplify presentation, we collapse this continuous process into a discrete process, dividing costs into pretrial costs that must be incurred before a defendant makes a settlement offer or goes to trial, and trial costs that must be incurred to obtain a verdict from the court. We denote date- $t$ pre-trial costs by $k_{p t} \geq 0$. If a lawsuit then goes to trial, a date- $t$ plaintiff must pay the additional trial costs of $c_{p t} \geq 0$. Recalling the definition of date 1 as the first moment at which a serious plaintiff found it worthwhile to file a lawsuit, there is an implicit premise that the potential gains to the plaintiff from filing exceed the costs, i.e., $\pi m_{1} \geq c_{p 1}+k_{p 1}$. This admits the possibility that the first case is in some way "unusual".

If a lawsuit is filed against the defendant at date $t, D$ incurs pre-trial costs of $k_{d t}>0$. If the case

\footnotetext{
${ }^{8}$ We allow the plaintiff to withdraw a negative expected value lawsuit to ensure that a plaintiff who has a meritless case cannot simply enter with a commitment to go to trial if there is no settlement and thereby extort money from a defendant. See Rosenberg and Shavell (1985) and Bebchuk (1988).
} 
then goes to trial, $D$ incurs additional trial costs of $c_{d t}>0$. The dating allows for the possibility that initial trial costs may exceed those in subsequent trials. For example, in subsequent cases, a defendant's expert may need less time to prepare, and much of the discovery work has been done. ${ }^{9}$ The defendant's payoff is her initial wealth $W$ less any payments made to plaintiffs and litigation costs incurred. We assume that the defendant is wealthy enough that there are no bankruptcy concerns. ${ }^{10}$ It eases presentation to describe the defendant's payoffs as net of her initial wealth.

The timing is as follows: (1) Date 1: Along the equilibrium path $P_{1}$ files a lawsuit. (2) $D$ makes a take-it-or-leave-it settlement offer $s_{1} \in[0, \infty)$ to $P_{1}$. (3) $P_{1}$ chooses whether to withdraw the case, accept the offer, or reject the offer. If $P_{1}$ accepts the offer, he is paid $s_{1}$. If $P_{1}$ rejects the offer, the case goes to trial. (4) The date-1 trial outcome is realized and payment is made. (5) Date 2: All date- 2 plaintiffs observe date- 1 outcomes and decide whether to enter. (6) $D$ makes take-it-orleave-it settlement offers $s_{2} \in[0, \infty)$ to date-2 plaintiffs who file. (7) Each date-2 plaintiff chooses whether to withdraw his case, accept the offer, or reject the offer. A plaintiff who accepts the offer is paid $s_{2}$. Date-2 cases that are not settled or withdrawn go to trial. (8) Date-2 trial outcomes are realized and payments are made. Figure 1 shows the timing.

We analyze the Perfect Bayesian Equilibrium of this game. Since the defendant makes take-itor-leave-it offers, in equilibrium a plaintiff must always accept an offer when indifferent between accepting or not, since an infinitesimally higher settlement offer would break the indifference. To ease exposition, we assume that when indifferent between entering and not entering, a plaintiff chooses not to enter. This allows us to make "if and only if" statements.

We solve for equilibrium outcomes recursively. The probability that a date-2 plaintiff wins can depend on the outcome of date- 1 litigation. We denote the posterior probability that a date- 2 plaintiff wins by $q$. Since both $D$ and $P_{1}$ have no private information, neither a date-1 settlement nor a withdrawal of a suit by $P_{1}$ conveys information to potential date- 2 plaintiffs about their probabilities of winning in trial, so following either of these outcomes, their posteriors remain $q=\pi$. In contrast, a date- 1 trial serves as a test or signal that conveys information to potential date-2 plaintiffs: following a plaintiff-win, their posteriors optimistically rise to $\bar{\pi}$, but following a defendant-win, their posteriors pessimistically fall to $\underline{\pi}$. By the Law of Iterated Expectations,

\footnotetext{
${ }^{9}$ One can also model the possibility that date- 2 costs, $k_{d 2}$ and $c_{d 2}$, depend on the history. Plausibly date- 2 costs could depend on whether a previous case settles or goes to trial. Allowing a date-1 trial to reduce a defendant's date- 2 trial costs (e.g., because she need not duplicate trial preparation efforts) or to reduce the date- 2 trial costs of an initial plaintiff's lawyer who also has a stake in future cases creates additional, straightforward incentives to go to trial.

${ }^{10}$ Bankruptcy concerns (e.g., with asbestos litigation) create incentives for a defendant to go to trial in the first litigation because the limited liability bounds her downside risk. We ignore this occasionally important, but well-studied (Spier 2002), incentive to go to trial, in order to focus on other strategic incentives to go to trial in sequential litigation.
} 


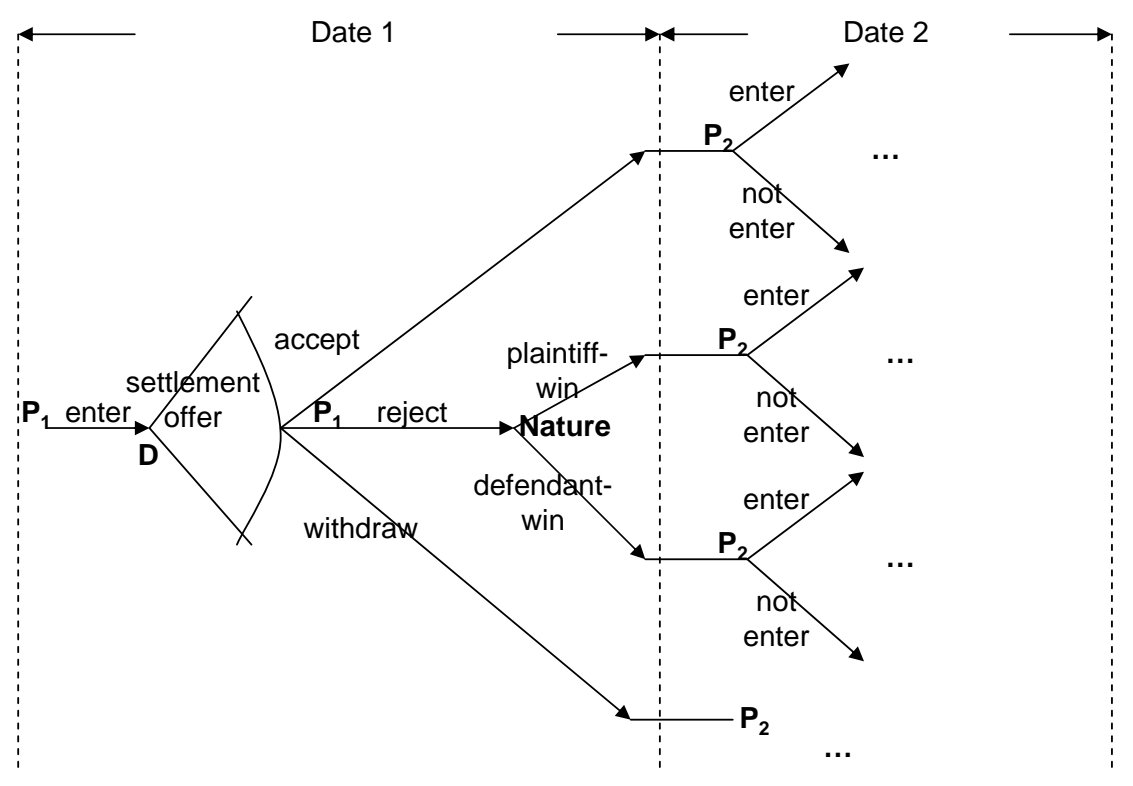

Figure 1: Timing of the game

$\pi \bar{\pi}+(1-\pi) \underline{\pi}=\pi$. Thus, at date $2, q \in\{\bar{\pi}, \pi, \underline{\pi}\}$. We begin with a preliminary result establishing that once learning about trial outcomes has occurred, all cases will be settled.

Lemma 1. Date-2 plaintiffs enter if and only if $q m_{2}>k_{p 2}+c_{p 2}$. Along the equilibrium path, after entry, $D$ settles every date-2 case by offering each date-2 plaintiff $q m_{2}-c_{p 2}$.

This lemma conveys how and when the outcome of the initial litigation affects the decisions by future potential date-2 plaintiffs on whether or not to file lawsuits:

Proposition 1. Decisions by date-2 plaintiffs to file lawsuits depend on the resolution of the initial case as follows:

Case 1. $\bar{\pi} m_{2} \leq k_{p 2}+c_{p 2}$. Date-2 plaintiffs do not enter regardless of the date-1 outcome.

Case 2. $\pi m_{2} \leq k_{p 2}+c_{p 2}<\bar{\pi} m_{2}$. Date-2 plaintiffs enter if and only if the plaintiff wins a date-1 trial.

Case 3. $\underline{\pi} m_{2} \leq k_{p 2}+c_{p 2}<\pi m_{2}$. Date-2 plaintiffs enter unless the defendant wins a date-1 trial.

Case 4. $k_{p 2}+c_{p 2}<\underline{\pi} m_{2}$. Date-2 plaintiffs enter regardless of the date-1 outcome.

In Cases 1 and 4, date-1 outcomes do not affect date- 2 entry decisions by plaintiffs. In Case 2 , a date-1 trial encourages entry relative to a date- 1 settlement, because a plaintiff-win causes future plaintiffs to update sufficiently optimistically about their chances that they file, when they 
otherwise would not. In contrast, in Case 3, a date-1 trial discourages entry relative to a settlement, by causing future plaintiffs to update sufficiently negatively about their chances following a win by the defendant that they choose not to file, when they otherwise would file.

Thus, in Case 3, a date-1 trial deters entry with probability $1-\pi$. When deciding whether to settle the initial plaintiff lawsuit, or to fight it at a trial, the defendant weighs the impact of possible date- 1 trial outcomes on decisions of potential future plaintiffs to file. We now show that a necessary condition for the defendant not to settle the initial case is that a defense-win is required to deter future plaintiffs from filing. An implication is that a sequential litigation structure is necessary for a trial to occur at date 1 . Specifically, if $N_{2}=0$, so there are no future potential plaintiffs, or if $\rho=0$, so that a date- 1 trial outcome has no bearing on date- 2 outcomes, then a trial never occurs in equilibrium: the logic in Lemma 1 implies that $D$ will settle with plaintiff $P_{1}$ at date 1 .

The full necessary and sufficient conditions for the initial lawsuit to go to trial are as follows:

Proposition 2. In equilibrium, when the plaintiff makes all legal decisions, the initial case goes to trial if and only if the following conditions on the date-2 litigation both hold:

1. Future lawsuits can be deterred, but only if the defendant wins the initial trial: $\underline{\pi} m_{2} \leq$ $k_{p 2}+c_{p 2}<\pi m_{2}$

2. The benefits to the defendant from possibly deterring date-2 lawsuits outweigh the extra date-1 trial costs: $(1-\pi)\left(\underline{\pi} m_{2}-c_{p 2}+k_{d 2}\right) N_{2}>c_{p 1}+c_{d 1}$.

Condition 1 just restates the conditions for Case 3 in Proposition 1. To understand Condition 2 , let $U_{t}^{S}$ denote $D$ 's date- $t$ payoff from settling at date 1 with the lowest acceptable offer, and let $U_{t}^{T}$ denote $D$ 's date- $t$ payoff from going to trial at date 1 (by making an unacceptable offer). Let $U^{S} \equiv U_{1}^{S}+U_{2}^{S}$, and $U^{T} \equiv U_{1}^{T}+U_{2}^{T}$.

Following a settlement, the posterior is $\pi$, so $D$ 's payoff from date-2 litigation is:

$$
U_{2}^{S}=\left(-\pi m_{2}+c_{p 2}-k_{d 2}\right) N_{2}
$$

Following a trial, there are two possibilities. If the outcome was a plaintiff-win, the posterior becomes $\bar{\pi}$ and $D$ 's payoff is $\left(-\bar{\pi} m_{2}+c_{p 2}-k_{d 2}\right) N_{2}$ because $D$ would offer $\bar{\pi} m_{2}-c_{p 2}$ to each plaintiff that then enters. If the outcome was a defendant-win, the posterior is $\underline{\pi}$ and $D$ 's payoff is 0 because no plaintiff enters. Therefore, $D$ 's expected payoff at date 2 following a date- 1 trial is:

$$
U_{2}^{T}=\pi\left(-\bar{\pi} m_{2}+c_{p 2}-k_{d 2}\right) N_{2}
$$


Contrasting $D$ 's date-1 payoff from a trial versus a settlement, the trial brings a loss of $U_{1}^{S}-U_{1}^{T}=$ $c_{p 1}+c_{d 1}$ at date 1 because $D$ incurs her trial cost and fails to make an offer which, due to the take-it-or-leave-it offer structure, could have extracted the rents from $P_{1}$ circumventing her trial costs. However, the possible gain at date $2, U_{2}^{T}-U_{2}^{S}$, from a defendant-win that discourages future plaintiffs from filing may outweigh it. The difference is:

$$
U^{T}-U^{S}=\left(U_{2}^{T}-U_{2}^{S}\right)-\left(U_{1}^{S}-U_{1}^{T}\right)=(1-\pi)\left(\underline{\pi} m_{2}-c_{p 2}+k_{d 2}\right) N_{2}-\left(c_{p 1}+c_{d 1}\right) .
$$

Condition 2 in Proposition 2 is exactly the condition that $U^{T}>U^{S}$.

Proposition 2 shows that a defendant's incentive to take the initial case to trial does not rise monotonically with the future litigation stakes, $m_{2}$. The future stakes must be high enough to make it worthwhile for $D$ to deter future plaintiffs from filing (Condition 2), and they must be high enough that a settlement does not deter date-2 plaintiffs from entering. However, the stakes cannot be so high that future plaintiffs still want to go to trial even if the defendant wins the initial trial.

Relatedly, a defendant's incentive to take the initial case to trial is not monotone in the prior, $\pi$. From Condition 1, if the prior that a plaintiff will win is too high, then the defendant cannot deter future plaintiffs; and conversely, if $\pi$ is too low, then a defendant need not go to trial to deter future plaintiffs. There is also an important subtlety in how the prior enters Condition 2: A higher $\pi$ implies that deterring entry is more difficult as $\underline{\pi}$ is higher; but conditional on deterring entry, a higher $\pi$ means that the defendant saves more from deterring entry (as the settlement payment upon entry would have been higher).

A defendant can gain from deterring date-2 plaintiffs for two reasons: (1) $D$ saves by not incurring pre-trial cost $k_{d 2}$, and (2) it may reduce the expected settlement payment to date-2 plaintiffs. Interestingly, this reduction in expected settlement payments can happen only because a plaintiff's pre-trial cost $k_{p 2}$ is positive. To understand why, let $h(q)$ be the settlement payment to a date 2 plaintiff who would win with probability $q$, and first consider $k_{p 2}=0$. When $q m_{2}-c_{p 2}<0$, date- 2 plaintiffs would not enter, and the settlement payment would be 0 ; and when $q m_{2}+c_{p 2}>0$, the settlement payment $h(q)$ is positive and linear in $q$. Therefore, $h(q)=\max \left\{q m_{2}-c_{p 2}, 0\right\}$ (see Figure 2(a)). Since $h(q)$ is a convex function of $q$, by Jensen's Inequality, $E[h(q)]>h(E[q])$. That is, the expected settlement payment under a date- 1 trial that spreads the beliefs to $\bar{\pi}$ and $\underline{\pi}$ exceeds that following a date- 1 settlement that keeps beliefs at $\pi$. Now consider $k_{p 2}>0$. The settlement payment is 0 whenever $q m_{2}-c_{p 2}-k_{p 2}<0$, so the settlement payment takes the form in Figure 2(b). However, $h(q)$ is no longer convex, and there is an interval of the prior probability $\pi$ for 
which $E[h(q)]<h(E[q]) .{ }^{11}$ On this range of the prior probability, a defendant-win deters date-2 plaintiffs who would extract positive settlements from $D$ were they to enter (but not a large enough settlement to cover their pre-trial costs of $k_{p 2}$ to give them incentives to enter). When this happens, the expected future settlement payments are reduced by spreading beliefs via a date- 1 trial.
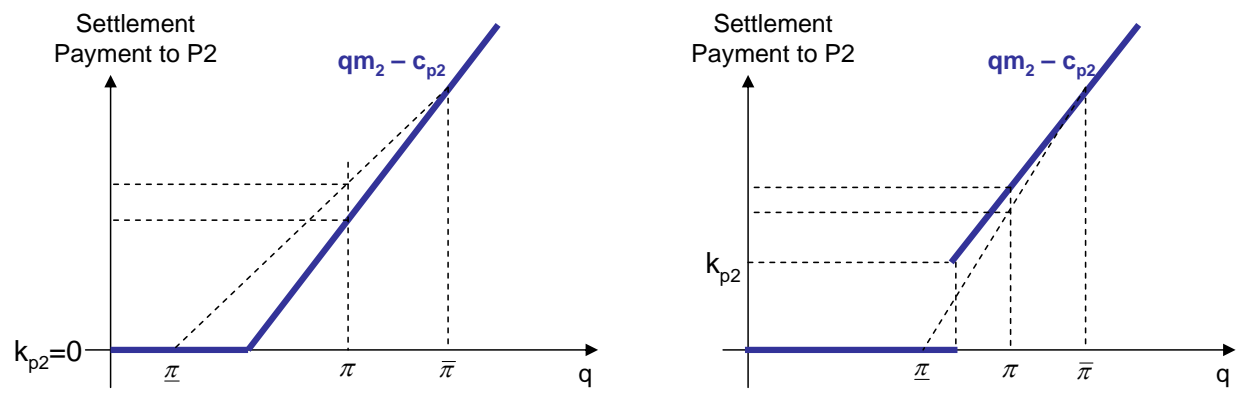

Figure 2: (a) settlement payment if $k_{p 2}=0$; (b) settlement payment if $k_{p 2}>0$.

Importantly, the circumstances under which the initial case goes to trial grow with the two central features of sequential litigation: (1) the number $N_{2}$ of subsequent cases whose trial outcomes would be affected by the initial trial outcome, and (2) the extent to which trial outcomes are correlated. That is, the larger is $N_{2}$, the greater is a defendant's gain from deterring future lawsuits; and the greater is the correlation in trial outcomes, the more negatively plaintiffs update following a defendant-win, spreading the difference in beliefs $\pi-\underline{\pi}$ about future trial outcomes following a settlement versus a defendant-win, making it "easier" for a defendant-win to deter entry. A caveat to this observation is that increased correlation in trial outcomes also reduces the benefit that the defendant derives from actually deterring entry (i.e., Condition 2 is harder to satisfy). However, when $N_{2}$ is large enough, the savings from deterring entry exceed the one set of trial costs incurred, so the crucial condition becomes the ability for the defendant to deter future plaintiffs with a defendant-win.

The conditions under which substantial learning in sequential litigation causes the initial case to go to trial are quite plausible. In particular, the potential savings on future pre-trial costs can be more than enough to cover the costs incurred in a single trial. Nonetheless, there is a limited extent to which learning on its own will lead to trials. First, once precedents have been established and potential plaintiffs have updated about their prospects at trial, any future lawsuits that are filed will be settled. Second, only a limited set of combinations of the prior $\pi$ and trial stakes $m_{2}$ causes future potential plaintiffs to be deterred by a defendant-win, but not by a settlement. We next con-

\footnotetext{
${ }^{11}$ The interval for $\pi$ is $\left(\max \left\{\frac{c_{p 2}}{m_{2}(1-\rho)}, \frac{c_{p 2}+k_{p 2}-m_{2} \rho}{m_{2}(1-\rho)}\right\}, \frac{c_{p 2}+k_{p 2}}{m_{2}(1-\rho)}\right]$.
} 
sider a variety of scenarios in which additional properties of sequential litigation increase the set of circumstances under which trials emerge.

\subsection{Delegation to Plaintiff Attorney}

In practice, plaintiffs often delegate legal decisions to their attorneys. To highlight the consequences of such delegation by the plaintiff, we suppose that the defendant continues to make the decisions for the defense. This latter assumption captures the observation that a defendant's attorney's interest is typically aligned with the defendant, for example because the attorney is an in-house counsel and/or in a repeated relationship with the defendant. We first show that delegation does not change our qualitative findings if the date-1 plaintiff's attorney has no stake in future cases.

We denote a date- $t$ plaintiff attorney by $P A_{t}$. We first assume that the initial plaintiff's attorney, $P A_{1}$ has no date- 2 clients. A plaintiff's attorney is paid on a pure contingent fee basis, receiving a fraction $\beta \in(0,1]$ of any settlement/damage. We take the commission rate $\beta$ as an exogenous industry standard and assume that litigation costs are entirely borne by the attorneys. Here, $\beta=1$ corresponds to our no-delegation, base-case, scenario. When $\beta<1$, a plaintiff attorney has a lesser incentive to enter litigation than the plaintiff himself, because the attorney only receives a fraction $\beta$ of the reward, but incurs all of the costs. Thus, the condition underlying the maintained premise that $P_{1}$ is the initial plaintiff to file becomes more stringent: $\beta \pi m_{1}>c_{p 1}+k_{p 1} \cdot{ }^{12}$ The rest of the setup mirrors our base-case formulation, and the analysis follows similarly.

Now, given a probability $q$ of winning at date 2 , if $\beta q m_{2} \leq c_{p 2}$, the defendant would offer a settlement of zero to any plaintiff who enters. If, instead, $\beta q m_{2}>c_{p 2}$, then the lowest settlement offer that a date-2 plaintiff's attorney would accept is:

$$
\beta s_{2}=\beta q m_{2}-c_{p 2} \Rightarrow s_{2}=q m_{2}-\frac{c_{p 2}}{\beta} .
$$

Compared to when plaintiffs' legal decisions are not delegated, from the defendant's perspective, it is as if the plaintiff's costs are scaled up by $\frac{1}{\beta}$. Since the plaintiff's attorney only receives $\beta$ share of any payments, he puts more weight on his costs than on the stakes of a case. Thus, in his decision making, it is as if the stakes are unchanged, but costs are inflated by $\frac{1}{\beta}$. As a result, a defendant can reduce her settlement offer. On the plaintiff's side, compared to the date-1 plaintiff, his attorney views both the payment and the costs incurred by the defendant as scaled down by $\beta$.

\footnotetext{
${ }^{12}$ This condition is sufficient for the initial case to go to trial in all other scenarios considered. The point that an attorney under a contingent fee has less incentive to bring a lawsuit and less incentive to go to trial is made by Miller (1987).
} 
Relative to the base-case scenario, when a plaintiff's attorney makes legal decisions, date-2 entry conditions are only altered by the weight $\beta$ placed on payoffs:

Proposition 3. When date-2 decisions to file lawsuits are made by a plaintiff's attorney, their entry decisions depend on the outcome of the date-1 lawsuit as follows:

Case 1. $\beta \bar{\pi} m_{2} \leq k_{p 2}+c_{p 2}$. No plaintiffs enter, regardless of date-1 outcomes.

Case 2. $\beta \pi m_{2} \leq k_{p 2}+c_{p 2}<\beta \bar{\pi} m_{2}$. Date-2 plaintiffs enter if and only if the plaintiff wins a date-1 trial.

Case 3. $\beta \underline{\pi} m_{2} \leq k_{p 2}+c_{p 2}<\beta \pi m_{2}$. Date-2 plaintiffs enter unless the defendant wins a date-1 trial.

Case 4. $k_{p 2}+c_{p 2}<\beta \underline{\pi} m_{2}$. Date-2 plaintiffs enter regardless of date-1 outcomes.

Proposition 4. In equilibrium, when the plaintiff's attorney makes all legal decisions, the initial case goes to trial if and only if the following conditions on date-2 litigation both hold:

1. A date-1 defendant-win is required to deter a plaintiff's attorney from filing date-2 lawsuits: $\beta \underline{\pi} m_{2} \leq k_{p 2}+c_{p 2}<\beta \pi m_{2}$,

2. The benefit to the defendant from possibly deterring date-2 lawsuits outweigh the extra date1 trial costs: $(1-\pi)\left(\underline{\pi} m_{2}-\frac{c_{p 2}}{\beta}+k_{d 2}\right) N_{2}>\frac{c_{p 1}}{\beta}+c_{d 1}$.

The result and proof mirror those for Proposition 2, save that the requisite adjustments in the stakes in Condition 1 and the plaintiff's costs in Condition 2. Only the stakes in condition 1, and not the costs are adjusted, while only the costs and not the stakes are adjusted in Condition 2. This is because Condition 1 is from the perspective of the plaintiff, while Condition 2 is from the perspective of the defendant. For the defendant, the expected difference between the payoffs from a date-1 trial and a date- 1 settlement becomes:

$$
U^{T}-U^{S}=(1-\pi)\left(\underline{\pi} m_{2}-\frac{c_{p 2}}{\beta}+k_{d 2}\right) N_{2}-\left(\frac{c_{p 1}}{\beta}+c_{d 1}\right)
$$

This gives Condition 2.

\subsection{Date-1 attorney represents future plaintiffs}

We have assumed that the initial plaintiff's attorney is not involved in date-2 litigation. However, in practice, an attorney may repeatedly engage in litigation against the same defendant. We 
now consider how outcomes are affected when the date-1 plaintiff's attorney may represent future plaintiffs. We first study the case where the outcome of date-1 litigation does not affect his share of potential date- 2 clients.

Suppose that regardless of date-1 litigation outcomes, $P A_{1}$ will represent share $\alpha \in[0,1]$ of date-2 plaintiffs, where $\alpha=0$ corresponds to the base-case scenario analyzed in Section 2.1. We now show that the greater are $P A_{1}$ 's future business ties, the greater are the circumstances under which the defendant decides to take the initial case to trial.

Proposition 5. The greater is the share $\alpha$ of future plaintiffs that the initial plaintiff's attorney will represent, the more attractive it is for the defendant to take the initial case to trial. In equilibrium, the initial lawsuit goes to trial if and only if the following conditions on date-2 litigation both hold:

1. Future lawsuits can be deterred, but only if the defendant wins the initial trial: $\beta \underline{\pi} m_{2} \leq$ $k_{p 2}+c_{p 2}<\beta \pi m_{2}$,

2. The benefit to the defendant from possibly deterring date-2 lawsuits outweigh the extra date1 trial costs: $(1-\pi)\left(\underline{\pi} m_{2}-\frac{c_{p 2}}{\beta}+k_{d 2}\right) N_{2}+(1-\pi)\left(\frac{c_{p 2}+k_{p 2}}{\beta}-\underline{\pi} m_{2}\right) \alpha N_{2}>\frac{c_{p 1}}{\beta}+c_{d 1}$.

Condition 1 for a trial is unchanged from that in Proposition 4. However, the possibility of repeat business makes it easier to satisfy Condition 2. When the date-1 plaintiff's attorney has a future stake in date- 2 outcomes, he begins to care about differences in the information revealed by a date-1 trial versus a settlement. When a defendant's win deters entry-a necessary condition for a date-1 trial to emerge-it follows that a date- 1 trial reveals information to the plaintiff's attorney that helps him fine tune date- 2 decisions about whether to file lawsuits. Now, the attorney only files future lawsuits when the chances of winning are high, and hence the settlement offer is high. In this way, a date- 1 trial increases the attorney's expected date- 2 payoff. Consequently, to settle the initial case, the defendant must compensate $P A_{1}$ for this loss of information. This more expensive settlement raises the attraction of a trial to the defendant.

Let $V_{2}^{T}$ denote $P A_{1}$ 's expected date-2 payoff when there is a date-1 trial, and $V_{2}^{S}$ denote his corresponding payoff when there is a settlement. Then compared to when the plaintiff's attorney has no future clients, the defendant must increase her settlement offer $s_{1}$ by $\frac{V_{2}^{T}-V_{2}^{S}}{\beta}$ to compensate the attorney for the foregone value of information that could be revealed at a trial, where

$$
\frac{V_{2}^{T}-V_{2}^{S}}{\beta}=(1-\pi)\left(\frac{c_{p 2}+k_{p 2}}{\beta}-\underline{\pi} m_{2}\right) \alpha N_{2}>0 .
$$

Condition 1 implies that this term is positive. This is exactly the term added to the LHS of Condition 2 compared to its counterpart in Proposition 4. The conditions favoring a trial are enhanced 
precisely because any settlement offer must contain this extra compensation to induce the initial plaintiff to forgo learning about future trial outcomes by going to trial in the initial case. That is, the gain of a trial over a settlement here is the original date- 2 gain with a plaintiff attorney who has no future business considerations plus the information benefit of a trial $\frac{V_{2}^{T}-V_{2}^{S}}{\beta}$ :

$$
U^{T}-U^{S}=(1-\pi)\left(\underline{\pi} m_{2}-\frac{c_{p 2}}{\beta}+k_{d 2}\right) N_{2}-\left(\frac{c_{p 1}}{\beta}+c_{d 1}\right)+(1-\pi)\left(\frac{c_{p 2}+k_{p 2}}{\beta}-\underline{\pi} m_{2}\right) \alpha N_{2} .
$$

It also follows that the conditions under which it is optimal for the initial plaintiff's attorney to engage in the initial litigation are relaxed compared to when he has no stakes in future litigation. ${ }^{13}$

The greater is the share $\alpha$ of future plaintiffs that the initial plaintiff represents, the more attractive a trial is to $D$ relative to a settlement, because $P A_{1}$ internalizes more of the informationrevealing benefit of a trial. In fact, when $P A_{1}$ represents all future potential plaintiffs, i.e., when $\alpha=1$, the decision of whether or not to take the initial case to trial maximizes the "joint surplus" of the defendant and plaintiff's attorney with $P A_{1}$ 's costs inflated by $\frac{1}{\beta}$. Thus, the choice to go to trial hinges on a comparison of the costs of deterring entry, $\frac{c_{p 1}}{\beta}+c_{d 1}$, with the benefits, which is just the saving of date-2 pre-trial costs, $(1-\pi)\left(\frac{k_{p 2}}{\beta}+k_{d 2}\right)$.

It is worth observing that when Condition 1 holds, but Condition 2 does not, so the initial case is settled, the initial plaintiff benefits from the increased settlement offer associated with an attorney who will engage in future litigation against the defendant. This implies that plaintiffs wants to seek out an attorney with future potential "conflicts of interest" of this form because they serve to commit the attorney to bargaining more strongly at date 1, demanding to be compensated for the value of information lost in a settlement.

\subsection{Plaintiff lawyer incentives to attract future clients}

We now model the possibility that the share of future plaintiffs is not fixed from the perspective of date 1 . In particular, potential plaintiffs may rely on the payment received by the initial plaintiff to assess the quality of his attorney. If the initial plaintiff's lawyer extracts a larger settlement, or wins a greater payment at trial, then he may attract more future clients. Advertisements by lawyers highlighting the size of settlements and trial awards won by their clients indicate that potential plaintiffs weigh them heavily in their choices of legal representation.

We do not model the informational primitives underlying why and how potential plaintiffs use the past payments to plaintiffs to learn about attorneys, because such details are unimportant given

\footnotetext{
${ }^{13}$ The conditions for $P A_{1}$ to enter at date 1 become $\beta \pi m_{1}>c_{p 1}+k_{p 1}-(1-\pi)\left(c_{p 2}+k_{p 2}-\beta \underline{\pi} m_{2}\right) \alpha N_{2}$.
} 
our focus. ${ }^{14}$ Rather, for simplicity, we assume that the date-1 plaintiff's attorney has a base of date- 2 clients of size $\alpha N_{2}$. On top of that, if he extracts a sufficiently high payment for his date-1 client, $x_{1} \geq w$, then all date-2 plaintiffs with cases against the defendant choose him to represent them. ${ }^{15}$ Thus, the cutoff $w\left(<m_{1}\right)$ simply measures what constitutes "doing well enough" for the date- 1 client that all date- 2 plaintiffs conclude that he is a good attorney and seek out his services. ${ }^{16}$ In particular, a date-1 trial victory for the plaintiff always encourages future plaintiffs to choose $P A_{1}$ as their attorney. Then, as a function of $x_{1}, P A_{1}$ expects to represent share $\alpha\left(x_{1}\right)$ of date-2 potential plaintiffs, where

$$
\alpha\left(x_{1}\right)= \begin{cases}1, & \text { if } x_{1} \geq w \\ \alpha, & \text { otherwise }\end{cases}
$$

To focus on the intertemporal linkages generated by the dependence of the initial plaintiff's attorney's future client base on date- 1 outcomes and how it can cause the defendant to take the initial case to trial, we assume away all correlation in trial outcomes, setting $\rho=0$. As a result, date- 1 trial outcomes contain no information about date-2 outcomes, $\underline{\pi}=\pi=\bar{\pi}$. Without any learning, date- 1 outcomes do not affect the number of date- 2 plaintiffs, so that this incentive to go to trial to deter future plaintiffs vanishes. Nonetheless, as we now show, the defendant may choose to go to trial rather than increase the settlement offer by enough to satisfy the initial plaintiff's attorney's desire to attract future clients.

Proposition 6. Suppose that trial outcomes are uncorrelated, but the initial plaintiff attorney's share of future plaintiffs rises by $1-\alpha$ if his initial client receives compensation of at least $w$. Then the initial lawsuit goes to trial at date 1 if and only if

1. $w>\pi m_{1}+c_{d 1}$, and

2. $\pi(1-\alpha)\left(\pi m_{2}-\frac{c_{p 2}+k_{p 2}}{\beta}\right) N_{2}>c_{d 1}+\frac{c_{p 1}}{\beta}$.

Condition 1 says that the defendant prefers having a trial at date 1 to settling at $w$ considering only her date-1 payoff. Note that the defendant does not care who represents the plaintiffs at date 2: from the defendant's perspective, date- 2 outcomes are not affected by whether or not she goes to trial at date 1 . The minimal acceptable offer to the plaintiff's attorney is $s_{1}=\pi m_{1}-\frac{c_{p 1}}{\beta}+\pi(1-\alpha)\left(\pi m_{2}-\frac{c_{p 2}+k_{p 2}}{\beta}\right) N_{2}$, reflecting that a trial brings an extra $(1-\alpha)$

\footnotetext{
${ }^{14}$ In our model, plaintiffs are otherwise indifferent to their selections of attorneys, so that any selection is optimal.

${ }^{15}$ This structure is without loss of generality: the plaintiff's attorney's decisions only hinge on the difference $1-\alpha$, i.e., he would make the same decisions if shares are $\alpha_{1}$ if $x_{1}<w$, and $\alpha_{2}$ if $x_{1} \geq w$, where $\alpha_{2}-\alpha_{1}=1-\alpha$.

${ }^{16}$ Incentives to go to trial would be further reinforced if the initial outcome also affected the initial plaintiff's attorney ability to attract future plaintiffs in cases unrelated to the current defendant.
} 
share of the date- 2 market with probability $\pi$. Condition 2 says that the costs of a settlement, i.e., the incremental cost of compensating the plaintiff for the extra share, exceed the benefits, i.e., the saving in the trial costs of the defendant plus the appropriately-weighted trial costs of the plaintiff's lawyer. It follows that a trial is preferred.

Increases in the market share $1-\alpha$ of date- 2 plaintiffs that a date- 1 plaintiff's lawyer would obtain if he wins at least $w$ for his client, or increases in the number $N_{2}$ of date-2 plaintiffs that raise the value of that share, both increase the payment that a defendant must pay to obtain a settlement, making a trial more attractive to her. Increases in the likelihood $\pi$ that a plaintiff wins at trial have possibly opposing effects. Increases in $\pi$ not only raise the stakes in the initial trial, but also the value of the future market share that only $P A_{1}$ cares about. The defendant does not want to compensate $P A_{1}$ for the added value of that future market share when she does not care who represents future plaintiffs, and this makes Condition 2 easier to satisfy; but, the increases in $\pi$ also mean that paying $w$ to settle becomes a smaller mark-up over what the defendant expects to pay in a trial, and this makes Condition 1 harder to satisfy. Similarly, a higher date- 1 payout $m_{1}$ to a plaintiff who wins favors a settlement with an offer at $w$ at date 1 , while higher date-2 payouts $m_{2}$ favor a date- 1 trial. Finally, note that the defendant's date- 2 pre-trial cost, $k_{d 2}$, no longer enters decisions of whether or not to go to trial. This is because we have assumed away all correlation in trial outcomes, and without learning, date- 1 outcomes do not affect the number of date-2 plaintiffs, eliminating this source for trials. ${ }^{17}$

\section{Meritless Cases}

We now return to our base case setting where trial outcomes are positively correlated and the plaintiff makes legal decisions in order to investigate how the existence of future meritless cases (cases without merits) can lead to trials. We first show how meritless cases at date 2 can give rise to trials at date 2. We then show how such date- 2 meritless cases increase the circumstances under which the initial date-1 case, which is known to have merits, goes to trial. In part, this reflects that a date-1 win by a defendant that deters future plaintiff cases with merits, also deters future meritless cases. More subtly, expected payouts to future plaintiffs can be a concave function of date- 2 beliefs about the probability of a plaintiff-win by a serious case due to the endogenous decisions to file meritless lawsuits. This creates an added incentive for a defendant to spread beliefs by going to trial at date 1 .

\footnotetext{
${ }^{17}$ Also note that the maintained premise that it is optimal for the initial lawsuit to be filed is relaxed relative to the base-case scenario to $\beta \pi m_{1}-\left(c_{p 1}+k_{p 1}\right)+\pi(1-\alpha)\left(\beta \pi m_{2}-c_{p 2}-k_{p 2}\right) N_{2}>0$.
} 
We modify our base-case model so that there is now a potential supply $F N_{2}$ of meritless cases at date 2 . These are cases that have a surface similarity with serious cases, but their lack of merit would be revealed in a trial. Our base-case scenario corresponds to $F=0$. Meritless cases incur the same litigation costs as serious ones. The only difference is that meritless cases never win in court. A plaintiff knows whether his case has merits, but the defendant does not. To ease analysis, we assume that the defendant's strategy at date 2 is a mapping from the posterior to a settlement offer- the defendant does not condition date- 2 decisions on the number of cases filed. ${ }^{18}$ Our analysis also ignores three hairline parameter cases, $\pi m_{2}=c_{p 2}+k_{p 2}, \underline{\pi} m_{2}=c_{p 2}+k_{p 2}$ and $\bar{\pi} m_{2}=c_{p 2}+k_{p 2}$, to avoid having to analyze uninteresting subgame equilibriums that only exist in these hairline cases. Our maintained assumption is that the very first case has merits.

We next characterize date-2 litigation outcomes when the posterior probability that a serious case wins in court is updated to $q$ following date- 1 litigation outcomes.

Lemma 2. (1) If $q m_{2}>c_{p 2}+k_{p 2}$ and $F>\frac{c_{p 2}+k_{p 2}}{q m_{2}-c_{p 2}}$, then in the date-2 subgame, the defendant's equilibrium payoffs are unique. All plaintiffs with serious cases file, and the expected number of meritless lawsuits is $\frac{c_{p 2}+c_{d 2}}{q m_{2}-c_{p 2}} N_{2}$. To any plaintiff that files, D offers a settlement $q m_{2}-c_{p 2}$ with probability $\frac{k_{p 2}}{q m_{2}-c_{p 2}}$ and goes to trial with the complementary probability.

(2) If $q m_{2}>c_{p 2}+k_{p 2}$ and $F \leq \frac{c_{p 2}+k_{p 2}}{q m_{2}-c_{p 2}}$, then in the unique date-2 subgame equilibrium, all plaintiffs file lawsuits, regardless of their merits. D offers $q m_{2}-c_{p 2}$ to settle each lawsuit.

(3) If $q m_{2}<c_{p 2}+k_{p 2}$, no plaintiffs file lawsuits at date 2.

In part (1) of Lemma 2 where there are many potential meritless cases, the mixed strategy equilibria reflect the "matching pennies" nature of the game. If too many meritless cases enter, $D$ would want to go to trial rather than settle all cases with an offer high enough that plaintiffs with serious cases would accept. But, then meritless lawsuits would not be filed. If, instead, meritless suits are unlikely, $D$ wants to settle. But then plaintiffs want to file meritless lawsuits. As a result, in any equilibrium, $D$ adopts a mixed strategy of sometimes pursuing a trial, and sometimes settling. Only the expected number of meritless cases enter a defendant's payoffs, so in addition to the symmetric equilibrium in which plaintiffs with meritless cases mix with a common probability, asymmetric equilibria also exist in which some plaintiffs with meritless cases always file, and some

\footnotetext{
${ }^{18}$ This is only relevant in the range characterized by a mixed strategy equilibrium, where the number of cases conveys information about the realized number of meritless cases filed. An equilibrium exists in which the number of meritless cases filed never differs by more than one. If $N_{2}$ is re-interpreted as an ex-ante expected number of serious date- 2 cases, none of our other analysis is altered, and the total number of cases can convey arbitrarily little information about the number of meritless cases filed, and hence have arbitrarily little effect on a defendant's behavior. We ignore this for simplicity, as it does not qualitatively affect date-1 decisions to go to trial.
} 
(or just one) mix between filing or not.

When a serious case is more likely to win at trial, the minimum acceptable settlement offer for a plaintiff with a serious case rises. This has two important implications. First, because the settlement offer is increased, in order to deter plaintiffs with meritless cases from filing, the defendant must be more likely to take a date-2 case to trial. Second, fewer meritless cases must be filed on average. Because the defendant must pay more to settle a serious case, it becomes more worthwhile for the defendant to weed out meritless cases. Thus, it takes fewer meritless cases to keep the defendant indifferent between paying the higher settlement offer and going to trial.

Part (2) reflects that when most cases have merit, the defendant prefers to settle all cases, paying a few unnecessary settlements, but avoiding trial costs. Plaintiffs with serious cases still enter if and only if $q m_{2}>c_{p 2}+k_{p 2}$ : the existence of meritless cases does not affect how serious cases react to date-1 litigation outcomes. Thus, Proposition 1 still characterizes their equilibrium behavior. At the same time, plaintiffs with meritless cases do not enter when those with serious cases do not enter, as part (3) of Lemma 2 indicates. Lemma 3 describes the consequences for a defendant's expected payoffs in future litigation.

Lemma 3. When a serious plaintiff expects to win a date-2 trial with probability $q$, the defendant's date-2 expected payoff is:

$$
g(q) \equiv \begin{cases}0, & \text { if } q<\frac{c_{p 2}+k_{p 2}}{m_{2}}, \\ \left(-q m_{2}+c_{p 2}-k_{d 2}\right) N_{2}(1+F), & \text { if } \frac{c_{p 2}+k_{p 2}}{m_{2}}<q<\frac{1}{m_{2}}\left(\frac{c_{p 2}+c_{d 2}}{F}+c_{p 2}\right), \\ \left(-q m_{2}+c_{p 2}-k_{d 2}\right) N_{2}\left(1+\frac{c_{p 2}+c_{d 2}}{q m_{2}-c_{p 2}}\right), & \text { if } q>\max \left\{\frac{c_{p 2}+k_{p 2}}{m_{2}}, \frac{1}{m_{2}}\left(\frac{c_{p 2}+c_{d 2}}{F}+c_{p 2}\right)\right\}\end{cases}
$$

The function $g(q)$ is continuous and weakly convex for $q>\frac{c_{p 2}+k_{p 2}}{m_{2}}$. Moreover, when $k_{d 2}\left(c_{p 2}+\right.$ $\left.c_{d 2}\right)>0$, it is strictly convex on the "mixed strategy range" of $q>\max \left\{\frac{c_{p 2}+k_{p 2}}{m_{2}}, \frac{1}{m_{2}}\left(\frac{c_{p 2}+c_{d 2}}{F}+c_{p 2}\right)\right\}$, where the defendant mixes between settling and going to trial.

When serious cases are too unlikely to win, no cases are filed at date 2 , so $D$ does not pay out anything. For an intermediate range of posterior probabilities $q$ (non-empty if and only if $F$ is small enough), all plaintiffs file, regardless of the merits of their cases, because there are not enough meritless cases to make it worthwhile for $D$ to go to trial to weed them out. When $q$ and $F$ are larger, all plaintiffs with serious cases file, but only some of those with meritless cases do, and the defendant responds by mixing between settling and going to trial.

The defendant's payout $-g(q)$ is concave over the range of $q$ with positive date- 2 entry. The payout rises linearly with $q$ on the range where all meritless cases enter because the expected payout to a serious case in trial, $q m_{2}$, is linear in $q$ and the number of cases filed $N_{2}(1+F)$ does not 
vary with $q$. Once the probability that a plaintiff with a serious case is high enough that only some meritless cases are filed, the payout becomes strictly concave in $q$ due to the nature of the mixed strategy equilibria. When $q$ is higher (a more promising case for serious plaintiffs), to keep $D$ indifferent between settling and going to trial, fewer meritless cases are filed. Thus, when the higher $q$ raises the requisite settlement offer, the reduction in meritless cases filed partially offsets the higher payout to plaintiffs relative to a linear increase. Conversely, when $q$ is lower (a less promising case for plaintiffs), more meritless cases file, which partially offsets the decrease in payout relative to a linear decrease. Therefore, the defendant's expected payout to plaintiffs is a strictly concave function of $q$ on the mixed strategy range of $q$, i.e., when the defendant's payoff is strictly convex.

Proposition 7. The circumstances under which a trial occurs increases in the proportion of potential meritless cases, F. In equilibrium, the initial case goes to trial if and only if either of the two following scenarios on date-2 litigation hold:

Scenario 1: $\quad$ 1. $\underline{\pi} m_{2} \leq k_{p 2}+c_{p 2}<\pi m_{2}, \quad 2 . \pi g(\bar{\pi})-g(\pi)>c_{p 1}+c_{d 1}$,
Scenario 2:
3. $k_{p 2}+c_{p 2}<\underline{\pi} m_{2}$,
4. $\pi g(\bar{\pi})+(1-\pi) g(\underline{\pi})-g(\pi)>c_{p 1}+c_{d 1}$.

It is useful to contrast this result with our base case characterization in Proposition 2. In scenario 1 , Condition 1 is the standard condition that a date- 1 trial deters entry following a date- 1 defendant-win, but a settlement does not. As in Proposition 2, Condition 2 says that the benefit from the reduction in date- 2 costs due to the possibility of deterring entry more than offsets the costs of a date-1 trial. However, this condition is now easier to satisfy because the presence of meritless cases increases the gains from deterring entry by going to trial at date 1. The LHS of Condition 2 not only includes the reduction in expected payouts to serious cases, but also the expected reduction in payouts to meritless cases. Indeed, a trial may reduce an even greater expected proportion of meritless cases than of serious ones. For example, when $\pi$ and $\bar{\pi}$ are both in the mixed strategy range, a trial reduces the probability of meritless cases from $\frac{c_{p 2}+c_{d 2}}{\left(\pi m_{2}-c_{p 2}\right) F}$ to $\pi \frac{c_{p 2}+c_{d 2}}{\left(\pi m_{2}-c_{p 2}\right) F}$; the percentage reduction is greater for meritless cases since $\pi<\bar{\pi}$. So, too, when $\pi$ is not in the mixed strategy range, but $\bar{\pi}$ is, the reduction in their entry probability is from 1 to $\pi \frac{c_{p 2}+c_{d 2}}{\left(\bar{\pi} m_{2}-c_{p 2}\right) F}$.

Scenario 2 says that even when a defendant-win fails to deter plaintiffs who have serious cases (Condition 3), when Condition 4 holds, the gains from deterring meritless cases still make it worthwhile to go to trial at date 1 , due to the convexity of $g(q)$. Going to trial causes date- 2 beliefs to diverge relative to a settlement, and because more meritless cases are now deterred when date-2 settlements are high $(q=\bar{\pi})$, than when they are low $(q=\underline{\pi})$, the associated gain (the LHS of Condition 4) may exceed the cost of a date-1 trial (the RHS of Condition 4). Indeed, in this scenario, 
in contrast to all previous scenarios analyzed, it can be optimal for the plaintiff to go to trial at date 1 even when there are no pre-trial cost savings, i.e., even when $k_{p 2}=k_{d 2}=0$. When $k_{d 2}=0$, the payout is a piece-wise linear (concave) function of the posterior, because fewer meritless cases enter when the posterior is high enough.

When a defendant is sufficiently likely to take date- 2 cases to trial, she deters all meritless cases. This might lead one to wonder whether and when a defendant would be better off if she could commit to taking all date- 2 cases to trial. Such commitment completely deters all meritless lawsuits, but it also incurs trial costs against all serious plaintiffs. We now show that when a plaintiff with a serious case is sufficiently likely to win at date 2 , a defendant would be better off committing to taking all cases to trial at the beginning of date 2 than she is in an equilibrium without commitment.

Proposition 8. If and only if (a) there are enough plaintiffs who can file meritless cases, and (b) $a$ plaintiff is likely enough to win at trial, a defendant would like to commit to going to trial at date-2:

1. When $q<\frac{c_{p 2}+k_{p 2}}{m_{2}}$, no plaintiffs file lawsuits, so commitment does not matter.

2. When $\frac{c_{p 2}+k_{p 2}}{m_{2}}<q<\frac{1}{m_{2}}\left(\frac{c_{p 2}+c_{d 2}}{F}+c_{p 2}-k_{d 2}\right)$, a defendant is better off not committing to trials.

3. When $q>\max \left\{\frac{c_{p 2}+k_{p 2}}{m_{2}}, \frac{1}{m_{2}}\left(\frac{c_{p 2}+c_{d 2}}{F}+c_{p 2}-k_{d 2}\right)\right\}$, a defendant is strictly better off committing to trials at date- 2 as long as $k_{d 2}>0$.

In situation 2, a plaintiff is sufficiently likely to win that plaintiffs file lawsuits, but a defendant is better off settling all cases, as the requisite settlement is not that high and/or there are not that many potential meritless cases. When $q$ and $F$ are large enough that $q>\max \left\{\frac{c_{p 2}+k_{p 2}}{m_{2}}, \frac{1}{m_{2}}\left(\frac{c_{p 2}+c_{d 2}}{F}+\right.\right.$ $\left.\left.c_{p 2}-k_{d 2}\right)\right\}$ (situation 3 ), a defendant would be better off committing to taking all cases to trial (provided her pre-trial costs are positive), in order to deter all meritless lawsuits.

\section{Nash Bargaining}

We have assumed that the defendant makes take-it-or-leave-it offers. However, our qualitative findings are unchanged if plaintiffs have more bargaining power. We illustrate this in the context where a plaintiff's attorney, who only represents his current client, makes all litigation decisions.

Suppose now that plaintiff attorneys have bargaining power $\lambda \in(0,1)$ and the defendant has bargaining power $1-\lambda$. Let $V$ be the outside option in date- 2 bargaining for a plaintiff's attorney, and let $U$ be $D$ 's outside option. Then at date 2, if a lawsuit is settled, the settlement solves:

$$
\max _{s}(-s-U)^{1-\lambda}(\beta s-V)^{\lambda} \Rightarrow s^{*}=(1-\lambda) \frac{V}{\beta}-\lambda U
$$


The outside options depend on whether a plaintiff's attorney wants to withdraw if bargaining fails. When $\beta q m_{2}<c_{p 2}, P A_{2}$ will withdraw, so the outside options are $V=U=0$. This implies that $s^{*}=0$. That is, without a credible threat, a plaintiff's attorney cannot extract a positive settlement in bargaining. When, instead, $\beta q m_{2}>c_{p 2}$, a plaintiff's attorney does not withdraw if bargaining fails and the case goes to trial. Therefore, $V \equiv \beta q m_{2}-c_{p 2}$ and $U \equiv-q m_{2}-c_{d 2}$. Thus, if they settle, a plaintiff's attorney receives $V+\lambda(-V-\beta U)$, and $D$ receives $U+(1-\lambda)\left(-\frac{V}{\beta}-U\right)$. Therefore, they settle if $-\frac{V}{\beta}-U>0$. Since $-\frac{V}{\beta}-U=-\frac{\beta q m_{2}-c_{p 2}}{\beta}-\left(-q m_{2}-c_{d 2}\right)=\frac{c_{p 2}}{\beta}+c_{d 2}>0$, they settle. That is, there is no trial at date 2. From $D$ 's perspective, the joint surplus is calculated by inflating the surplus of $P A_{2}$ by $\frac{1}{\beta}$. From $P A_{2}$ 's perspective, the joint surplus is calculated by deflating the surplus of $D$ by $\beta$. Let $\Delta_{2} \equiv\left(\frac{c_{p 2}}{\beta}+c_{d 2}\right)>0$. Parameter $\Delta_{2}$ is exactly the joint surplus of settling (from $D$ 's perspective) at date 2 between $D$ and any plaintiff that enters at date 2. Similarly, $\beta \Delta_{2}$ is the joint surplus of settling (from the perspective of the plaintiff's attorney).

Lemma 4 describes the decisions by date-2 plaintiff attorneys of whether to file lawsuits:

Lemma 4. (Bargaining with Attorney.) Let $\Delta_{2} \equiv\left(\frac{c_{p 2}}{\beta}+c_{d 2}\right)>0$. In the date-2 subgame, plaintiffs file lawsuits if and only if $\beta q m_{2}>\max \left\{c_{p 2}, c_{p 2}+k_{p 2}-\lambda \beta \Delta_{2}\right\}$.

There are essentially two necessary conditions for entry. One is that the plaintiff's attorney have a credible threat of trial, i.e., $\beta q m_{2}>c_{p 2}$ (the credible-trial condition). Otherwise, the consequence of rejecting a settlement offer is not a trial, but rather a voluntary withdrawal of the lawsuit. The other is that the bargaining settlement covers the pre-trial cost for the plaintiff. With t-i-o-l-i offers, the second condition implies the first, so only one condition describes the entry decision. However, when the plaintiff has enough bargaining power, the credible-trial condition becomes the binding condition for entry; thus, the two terms on the RHS of the entry condition in Lemma 4.

Proposition 9. (Bargaining with Attorney.) Let $\Delta_{2} \equiv\left(\frac{c_{p 2}}{\beta}+c_{d 2}\right)>0$. Then, in equilibrium there is a trial at date 1 if and only if the following conditions on the date-2 litigation hold:

1. $\beta \underline{\pi} m_{2} \leq \max \left\{c_{p 2}, c_{p 2}+k_{p 2}-\lambda \beta \Delta_{2}\right\}<\beta \pi m_{2}$

2. $(1-\pi)\left(\underline{\pi} m_{2}+c_{d 2}+k_{d 2}-(1-\lambda) \Delta_{2}\right) N_{2}>\frac{c_{p 1}}{\beta}+c_{d 1}$.

Increasing the bargaining power $\lambda$ of the plaintiff's attorney expands the circumstances under which a defendant takes the initial case to trial

Condition 1 again says that a defendant-win at a date- 1 trial is necessary to deter entry. Condition 2 is still the trade-off between settling and going to a trial at date 1 . The RHS of Condition 1 
is the cost of going to trial for $D$ and $P A_{1}$ from their joint perspectives. The LHS of Condition 2 is the defendant's date-2 gain from deterring date-2 lawsuits; $P A_{1}$ does not care about what happens in the future. In Condition 2, if $\lambda=0$, we are back to t-i-o-l-i offers. A defendant gains more from deterring date-2 lawsuits when plaintiffs have more bargaining power because she must pay more to settle if they enter. This makes Condition 2 easier to satisfy, i.e., greater plaintiff bargaining power increases the circumstances under which a defendant takes the initial case to trial.

\section{Conclusion}

Sequential litigation can arise when a single defendant injures multiple potential plaintiffs, and the plaintiffs become aware of the damage, or become capable of filing lawsuits, at different points in time. In this paper we identify several distinct features of sequential litigation that can render it worthwhile for a plaintiff and defendant to choose to incur the substantial expenses of a trial, rather than negotiate a settlement. We first observe that an initial trial outcome-whether the defendant wins or loses - conveys extensive information to future potential plaintiffs about their prospects at a trial. Trial outcomes convey more information than do settlements because plaintiffs learn whether a strategy works, whether a defendant has a particular vulnerability, and positive or negative precedents may be established. We show that, as a result, the initial lawsuit can go to trial when an initial defendant-win would cause future potential plaintiffs to update sufficiently negatively about their prospects that they are deterred from filing lawsuits, whereas a settlement would not. In addition, for a trial to occur, the savings from deterring future lawsuits must exceed the combined initial trial costs of the plaintiff and defendant. Thus, sequential litigation is likely to lead to trial when many future cases hinge sensitively on the outcome of the initial trial.

We show that the possibility of meritless lawsuits further raises the attraction of trials. When a defendant-win deters plaintiffs with serious cases, it also deters plaintiffs with meritless ones. Even when a defendant-win does not deter serious plaintiffs, when there are enough possible meritless cases, defendants will sometimes take future plaintiffs to trial, to weed out meritless cases. Ironically, in this situation, more plaintiffs with meritless cases are deterred following a defendant-loss than following a defendant-win, precisely because the amount required to settle a serious case is higher, making a defendant more eager to go to trial to avoid paying out to meritless cases. We also show that trials are more likely if the initial plaintiff's attorney may also represent future clients. This is both because the initial trial outcome can convey valuable information to the plaintiff's attorney about whether it is worthwhile to pursue future cases; and because the plaintiff's attor- 
ney's ability to attract future clients (at the expense of other attorneys, but not the defendant) may hinge sensitively on how much he can extract from the defendant for his initial client, giving the plaintiff's attorney a preference for a trial over a settlement. 


\section{References}

[1] Bebchuk, L. 1984. Litigation and Settlement under Imperfect Information. RAND Journal of Economics, 15, 404-15.

[2] Briggs, H. III, Huryn K., and McBride M. 1996. Treble Damages and the Incentive to Sue and Settle. RAND Journal of Economics, 27, 770-86.

[3] Bebchuk, L., 1988, Suing Solely to Extract a Settlement Offer, Journal of Legal Studies, 17, 437-50.

[4] Che, Y. and K. Spier, 2007, Exploiting Plaintiffs Through Settlement: Divide and Conquer. Harvard Law School John M. Olin Center for Law, Economics and Business Discussion Paper Series. Paper 591.

[5] Che, Y. and J. Yi, 1993, The Role of Precedents in Repeated Litigation. Journal of Law, Economics, \& Organization, 9, 399-424.

[6] Daughety, A. 2000. Settlement. In Encyclopedia of Law and Economics, ed. B Bouckaert, G De Geest, 5:95-158. Cheltenham, UK: Edward Elgar.

[7] Daughety, A. and Reinganum J. 1994. Settlement Negotiations with Two-sided Asymmetric Information: Model Duality, Information Distribution, and Efficiency. International Review of Law and Economics, 14, 283-98.

[8] Daughety, A. and J. Reinganum, 1999, Hush Money. The RAND Journal of Economics, 30, 661-678.

[9] Daughety, A. and J. Reinganum, 2002, Informational Externalities in Settlement Bargaining: Confidentiality and Correlated Culpability, The RAND Journal of Economics, Vol. 33, No. 4 (Winter, 2002), pp. 587-604.

[10] Daughety, A. and Reinganum J., 2004. Exploiting Future Settlements: a Signalling Model of Most-Favored-Nation Clauses in Settlement Bargaining. RAND Journal of Economics, 35, 467-85.

[11] Gross, S. and K. Syverud, 1991, Getting to No: A Study of Settlement Negotiations and the Selection of Cases for Trial. Michigan Law Review, 90, 319-393. 
[12] Hay, B. and Spier K., 1998. Settlement of Litigation. In The New Palgrave Dictionary of Economics and the Law, ed. P Newman, 3:442-51. New York: Stockton.

[13] Hua, X. and K. Spier, 2005, Information and Externalities in Sequential Litigation. Journal of Institutional and Theoretical Economics, 161, 215-232.

[14] Kearns, S., 1999, Note, Decertification of Statewide Tobacco Class Actions, New York University Law Review, 74, 1336-1348.

[15] Kornhauser, L. and Revesz R., 1994a. Multidefendant Settlements: the Impact of Joint and Several Liability. Journal of Legal Studies, 23, 41-76.

[16] Kornhauser, L. and Revesz R., 1994b. Multidefendant Settlements under Joint and Several Liability: the Problem of Insolvency. Journal of Legal Studies, 23, 517-42.

[17] Meurer, M., 1992. The Gains from Faith in an Unfaithful Agent: Settlement Conflict between Defendants and Liability Insurer. Journal of Law, Economics and Organization 8, 502-522.

[18] Miller, G., 1987, Some Agency Problems in Settlement. The Journal of Legal Studies, 16, 189-215.

[19] Priest, G. and B. Klein, 1984, The Selection of Disputes for Litigation, Journal of Legal Studies, 13, 1-55.

[20] Reinganum, J. and Wilde L. 1986. Settlement, Litigation, and the Allocation of Litigation Costs. RAND Journal of Economics, 17, 557-66.

[21] Rosenberg, D., 2002, Avoiding Duplicative Litigation of Similar Claims: the Superiority of Class Action vs. Collateral Estoppel vs. Standard Claims Market. Harvard Law School, Public Law Research Paper No. 44; Harvard Law and Economics Discussion Paper No. 394.

[22] Rosenberg, D. and S. Shavell, 1985, A Model in Which Suits Are Brought for Their Nuisance Value, International Review of Law and Economics, 5, 3-13.

[23] Spier, K., 1992, The Dynamics of Pretrial Negotiation. Review of Economic Studies, 59, 93-108.

[24] Spier, K., 2002, Settlement with Multiple Plaintiffs: The Role of Insolvency. Journal of Law, Economics, \& Organization, 18, 295-323. 
[25] Spier, K., 2003a. The Use of Most-Favored-Nation Clauses in Settlement of Litigation. RAND Journal of Economics 34, 78-95.

[26] Spier, K., 2003b. Tied to the Mast: Most-Favored-Nation Clauses in Settlement Contracts. Journal of Legal Studies, 32, 91-120.

[27] Spier, K. and Sykes, A., 1998. Capital Structure, Priority Rules, and the Settlement of Civil Claims. The International Review of Law and Economics, 18, 187-200.

[28] Sykes, A., 1994. Bad Faith' Refusal to Settle by Liability Insurers: Some Implications of the Judgment-Proof Problem. Journal of Legal Studies 23, 77-110.

[29] Yang, B., 1996. Litigation, Experimentation, and Reputation. International Review of Law and Economics, 16, 491- 502.

\section{Appendix}

Proof of Lemma 1. If $q m_{2} \leq c_{p 2}$, then $D$ 's date-2 settlement offer is 0 . This offer will be accepted because a date- 2 plaintiff does not have a credible threat to go to trial. $D$ has no incentive to make an unacceptable offer because $D$ expects a negative payoff of $-q m_{2}-c_{d 2}$ from a date- 2 trial. Thus, when a date- 2 plaintiff contemplates filing a suit, regardless of whether he accepts the zero offer or withdraws, his expected payoff from filing a lawsuit is negative due to the pre-trial cost $k_{p 2}$. Therefore, no date-2 plaintiff files if $q m_{2} \leq c_{p 2}$.

If $q m_{2}>c_{p 2}$, then $D$ 's settlement offer at date 2 is $q m_{2}-c_{p 2}>0$. This offer leaves a date-2 plaintiff indifferent between accepting and not. In equilibrium, plaintiffs accept this offer because otherwise $D$ can make the offer $\epsilon$ more attractive to break the indifference. Therefore, a date- 2 plaintiff's expected payoff from filing a lawsuit is $q m_{2}-c_{p 2}-k_{p 2}$. Since the payoff from not filing is 0 , a plaintiff files if and only if $q m_{2}-c_{p 2}-k_{p 2}>0$.

Proof of Proposition 2. If $\pi m_{2}<c_{p 2}+k_{p 2}$, no plaintiffs file. If $\pi m_{2} \geq c_{p 2}+k_{p 2}$, then settling with a date-2 plaintiff is better for $D$ than going to trial. Settling gives $D$ a payoff of $-\pi m_{2}+c_{p 2}-k_{d 2}$ in each case, but going to trial gives $D$ a payoff of $-\pi m_{2}-c_{d 2}$ in each case. Thus, settling yields a gain of $c_{p 2}+c_{d 2}$. So no trial happens in equilibrium. We break the analysis down according to the impact of the date- 1 outcome on plaintiff entry at date 2. Let $U_{1}^{S}$ denote $D$ 's date-1 payoff if $D$ settles at date 1 with the lowest acceptable offer. Let $U_{1}^{T}$ denote $D$ 's date-1 payoff if $D$ goes to trial (by making an unacceptable offer). The parameter cases here are the same as in Lemma 1. 
Case 1. Here, regardless of the date-1 outcome, no plaintiff files at date 2 . Then the settlement offer at date 1 only affects $D$ 's date-1 payoff. If $D$ settles, his payoff (not considering the pre-trial cost $\left.k_{d 1}\right)$ is $-\pi m_{1}+c_{p 1}$ because the lowest offer $P_{1}$ would accept is $\pi m_{1}-c_{p 1}$. If $D$ goes to trial, his payoff (not considering the pre-trial cost of $k_{d 1}$ ) is $-\pi m_{1}-c_{d 1}$. Therefore, by settling, $D$ gains $c_{p 1}+c_{d 1}$. This is the saving in joint surplus (to $D$ and $P_{1}$ ) from avoiding a date- 1 trial, which is completely extracted by $D$ because he can make t-i-o-l-i offers.

Case 2. In this parameter region, a plaintiff-win at date 1 causes all date-2 plaintiffs to file even though they would not after a date- 1 settlement. Following a date- 1 settlement, the date- 2 payoff is 0 . Following a date- 1 trial, the date- 2 expected payoff is $\pi\left(-\bar{\pi} m_{2}+c_{p 2}-k_{d 2}\right) N_{2}<0$ because $D$ would make a settlement offer of $\bar{\pi} m_{2}-c_{p 2}>k_{p 2}$ to each date-2 plaintiff that enters after a date-1 plaintiff-win. Hence, $D$ 's date- 2 payoff is higher with a date- 1 settlement than a date-1 trial. In addition, a date- 1 settlement brings a gain of $c_{d 1}+c_{p 1}$ to $D$ at date 1 over a date- 1 trial. Therefore, $D$ strictly prefers to settle at date 1 by offering $\pi m_{1}-c_{p 1}$ to $P_{1}$.

Case 3. In this parameter region, a date-1 defendant-win induces all date-2 plaintiffs not to file, whereas they would file following any other outcome. Following a date- 1 settlement, the date- 2 payoff is $U_{2}^{S}=\left(-\pi m_{2}+c_{p 2}-k_{d 2}\right) N_{2}$ because $D$ would offer $\pi m_{2}-c_{p 2}$ to settle each date-2 lawsuit. Following a date- 1 trial, the date- 2 expected payoff is $U_{2}^{T}=\pi\left(-\bar{\pi} m_{2}+c_{p 2}-k_{d 2}\right) N_{2}$ because $D$ would offer $\bar{\pi} m_{2}-c_{p 2}$ to settle each date-2 lawsuit following a plaintiff-win. The difference in payoffs for $D$ between a date- 1 trial and settlement is

$$
U^{T}-U^{S}=(1-\pi)\left(\underline{\pi} m_{2}-c_{p 2}+k_{d 2}\right) N_{2}-\left(c_{p 1}+c_{d 1}\right)
$$

Case 4. In this parameter region, all date-2 plaintiffs file suits regardless of the date-1 outcome. Following a date- 1 settlement, the date- 2 payoff is $\left(-\pi m_{2}+c_{p 2}-k_{d 2}\right) N_{2}$. Following a date- 1 trial, the date- 2 expected payoff for $D$ is $\pi\left(-\bar{\pi} m_{2}+c_{p 2}-k_{d 2}\right) N_{2}+(1-\pi)\left(-\underline{\pi} m_{2}+c_{p 2}-k_{d 2}\right) N_{2}=$ $\left(-\pi m_{2}+c_{p 2}-k_{d 2}\right) N_{2}$. Thus, the date-2 payoffs are the same under a date-1 settlement and a date- 1 trial. Comparing reveals that a date- 1 settlement brings a gain to $D$ of $c_{p 1}+c_{d 1}$.

Cases 1 - 4 exhaust all possibilities given that $\pi m_{1}>c_{p 1}+k_{p 1}$.

Proof of Proposition 5. Let $V_{2}^{T}$ denote the expected date-2 payoff of $P A_{1}$ when there is a trial at date 1 . Let $V_{2}^{S}$ denote the corresponding payoff when there is a settlement at date 1 . Then $s_{1}$ must increase by $\frac{V_{2}^{T}-V_{2}^{S}}{\beta}$ at date 1 to compensate an attorney with future clients compared to one without. In parameter cases 1 and $4, V_{2}^{T}-V_{2}^{S}=0$, since the date- 1 outcome does not affect date-2 entry decision of plaintiffs, so there is no trial at date 1 . 
Case 2. In this parameter region, a trial encourages entry with probability $\pi$.

$$
\frac{V_{2}^{T}-V_{2}^{S}}{\beta}=\pi\left(\bar{\pi} m_{2}-\frac{c_{p 2}+k_{p 2}}{\beta}\right) \alpha N_{2} .
$$

Therefore,

$$
\begin{aligned}
U^{T}-U^{S}= & \left(U_{1}^{T}+U_{2}^{T}\right)-\left(U_{1}^{S}+U_{2}^{S}\right) \\
& =\pi\left(-\bar{\pi} m_{2}+\frac{c_{p 2}}{\beta}-k_{d 2}\right) N_{2}-\left(\frac{c_{p 1}}{\beta}+c_{d 1}\right)+\pi\left(\bar{\pi} m_{2}-\frac{c_{p 2}+k_{p 2}}{\beta}\right) \alpha N_{2} \\
& \leq-\pi\left(\frac{k_{p 2}}{\beta}+k_{d 2}\right) N_{2}-\left(\frac{c_{p 1}}{\beta}+c_{d 1}\right)<0 .
\end{aligned}
$$

The inequality follows because $\alpha \leq 1$. Therefore, the date- 1 case is settled.

Case 3. In this parameter region, a trial deters entry with probability $1-\pi$.

$$
\frac{V_{2}^{T}-V_{2}^{S}}{\beta}=(1-\pi)\left(\frac{c_{p 2}+k_{p 2}}{\beta}-\underline{\pi} m_{2}\right) \alpha N_{2} .
$$

Therefore, there is a trial at date 1 if and only if,

$$
-(1-\pi)\left(-\underline{\pi} m_{2}+\frac{c_{p 2}}{\beta}-k_{d 2}\right) N_{2}-\left(\frac{c_{p 1}}{\beta}+c_{d 1}\right)+(1-\pi)\left(\frac{c_{p 2}+k_{p 2}}{\beta}-\underline{\pi} m_{2}\right) \alpha N_{2}>0 .
$$

Proof of Proposition 6. Since there is no correlation between date-1 and date-2 trial outcomes, date-2 plaintiffs believe the probability of winning to be $\pi$. When $\beta \pi m_{2} \leq c_{p 2}+k_{p 2}$, no plaintiff files a suit at date 2 , so $D$ settles at date 1 . If, instead, $\beta \pi m_{2}>c_{p 2}+k_{p 2}$, then all date-2 plaintiffs enter. It follows that $D$ 's date-2 payoff does not depend on date-1 outcomes, i.e., $U_{2}^{S}=U_{2}^{T}$.

Case A. $w>\pi m_{1}-\frac{c_{p 1}}{\beta}+\pi(1-\alpha)\left(\pi m_{2}-\frac{c_{p 2}+k_{p 2}}{\beta}\right) N_{2}$.

The offer $s_{1}^{*}=\pi m_{1}-\frac{c_{p 1}}{\beta}+\pi(1-\alpha)\left(\pi m_{2}-\frac{c_{p 2}+k_{p 2}}{\beta}\right) N_{2}$ makes $P A_{1}$ exactly indifferent between accepting and rejecting the offer because a trial brings extra $(1-\alpha)$ share of the date- 2 market with probability $\pi$. Any settlement offer above this level would be accepted. Any lesser offer would be rejected because $P A_{1}$ would strictly prefer to go to trial, instead. Therefore, if $D$ settles, he would offer $s_{1}^{*}$, which would yield $D$ a settlement payoff of:

$$
U^{S}=-\pi m_{1}+\frac{c_{p 1}}{\beta}-\pi(1-\alpha)\left(\pi m_{2}-\frac{c_{p 2}+k_{p 2}}{\beta}\right) N_{2}+U_{2}^{S}
$$

If $D$ instead goes to trial, her payoff is:

$$
U^{T}=-\pi m_{1}-c_{d 1}+U_{2}^{T} .
$$


The difference is:

$$
U^{T}-U^{S}=\pi(1-\alpha)\left(\pi m_{2}-\frac{c_{p 2}+k_{p 2}}{\beta}\right) N_{2}-\left(c_{d 1}+\frac{c_{p 1}}{\beta}\right)
$$

Thus, if $w$ satisfies Case A, a date-1 trial occurs if and only if $\pi(1-\alpha)\left(\pi m_{2}-\frac{c_{p 2}+k_{p 2}}{\beta}\right) N_{2}>$ $\left(c_{d 1}+\frac{c_{p 1}}{\beta}\right)$.

Case B. $\pi m_{1}-\frac{c_{p 1}}{\beta}+\pi(1-\alpha)\left(\pi m_{2}-\frac{c_{p 2}+k_{p 2}}{\beta}\right) N_{2} \geq w>\pi m_{1}-\frac{c_{p 1}}{\beta}-(1-\pi)(1-\alpha)\left(\pi m_{2}-\right.$ $\left.\frac{c_{p 2}+k_{p 2}}{\beta}\right) N_{2}$.

The lower bound on $w$ implies that any offer $s_{1} \geq w$ is accepted because:

$$
s_{1}+\left(\pi m_{2}-\frac{c_{p 2}+k_{p 2}}{\beta}\right) N_{2}>\pi m_{1}-\frac{c_{p 1}}{\beta}+(\alpha+\pi(1-\alpha))\left(\pi m_{2}-\frac{c_{p 2}+k_{p 2}}{\beta}\right) N_{2} .
$$

The upper bound on $w$ implies that any offer $s_{1}<w$ is rejected, so the optimal offer by $D$ would be $s_{1}^{*}=w$. Then,

$$
U^{S}=-w+U_{2}^{S}, \quad U^{T}=-\pi m_{1}-c_{d 1}+U_{2}^{T}
$$

Therefore, a trial happens at date 1 if and only if $w>\pi m_{1}+c_{d 1}$.

Case C. $\pi m_{1}-\frac{c_{p 1}}{\beta}-(1-\pi)(1-\alpha)\left(\pi m_{2}-\frac{c_{p 2}+k_{p 2}}{\beta}\right) N_{2} \geq w$.

Any offer less than $w$ is rejected. An offer $s_{1} \in\left[w, \pi m_{1}-\frac{c_{p 1}}{\beta}-(1-\pi)(1-\alpha)\left(\pi m_{2}-\right.\right.$ $\left.\frac{c_{p 2}+k_{p 2}}{\beta}\right) N_{2}$ ) is also rejected because:

$$
s_{1}+\left(\pi m_{2}-\frac{c_{p 2}+k_{p 2}}{\beta}\right) N_{2}<\pi m_{1}-\frac{c_{p 1}}{\beta}+(\alpha+\pi(1-\alpha))\left(\pi m_{2}-\frac{c_{p 2}+k_{p 2}}{\beta}\right) N_{2} .
$$

Also, any offer $\left.s_{1} \geq \pi m_{1}-\frac{c_{p 1}}{\beta}-(1-\pi)(1-\alpha)\left(\pi m_{2}-\frac{c_{p 2}+k_{p 2}}{\beta}\right) N_{2}\right)$ will be accepted for the same reason as in Case B. Therefore, the optimal settlement offer is $s_{1}^{*}=\pi m_{1}-\frac{c_{p 1}}{\beta}-(1-\pi)(1-$ $\alpha)\left(\pi m_{2}-\frac{c_{p 2}+k_{p 2}}{\beta}\right) N_{2}$. Then,

$$
U^{S}=-\pi m_{1}+\frac{c_{p 1}}{\beta}+(1-\pi)(1-\alpha)\left(\pi m_{2}-\frac{c_{p 2}+k_{p 2}}{\beta}\right) N_{2}+U_{2}^{S}>-\pi m_{1}-c_{d 1}+U_{2}^{T}=U^{T} .
$$

This implies $U^{S}>U^{T}$, so there is no trial at date 1 for Case C.

We first establish the sufficiency part of the Proposition 6. When Condition 1 is satisfied, then either $w$ is large enough that either Case A or Case B holds, in which case Condition 2 then implies that a trial happens at date 1 . We now establish the necessity part. There are two ways in which a trial happens: Case A or Case B. Condition 2 must hold in Case A, which is equivalent to $\pi m_{1}-\frac{c_{p 1}}{\beta}+\pi(1-\alpha)\left(\pi m_{2}-\frac{c_{p 2}+k_{p 2}}{\beta}\right) N_{2}>\pi m_{1}+c_{d 1}$. Since Case A also implies that 
$w>\pi m_{1}-\frac{c_{p 1}}{\beta}+\pi(1-\alpha)\left(\pi m_{2}-\frac{c_{p 2}+k_{p 2}}{\beta}\right) N_{2}$, we have $w>\pi m_{1}+c_{d 1}$. That is, Condition 1 is satisfied. If it is Case B, then $\pi m_{1}-\frac{c_{p 1}}{\beta}+\pi(1-\alpha)\left(\pi m_{2}-\frac{c_{p 2}+k_{p 2}}{\beta}\right) N_{2} \geq w>\pi m_{1}+c_{d 1}$. This directly contains Condition 1 and implies Condition 2.

Proof of Lemma 2. If $q m_{2}<c_{p 2}$, then $D$ offers $s_{2}=0$ at date 2 because even a serious case is withdrawn after such an offer and there is no credible threat of a trial.

Now suppose that $0<q m_{2}-c_{p 2}<k_{p 2}$. In any subgame equilibrium at date 2 with $q m_{2}>c_{p 2}$, $D$ makes one of two possible offers: $s_{2} \in\left\{q m_{2}-c_{p 2}, 0\right\}$, because any other offer is dominated by one of these offers. When $0<q m_{2}-c_{p 2}<k_{p 2}$, even when $D$ offers $q m_{2}-c_{p 2}$ for sure, no plaintiffs would want to file given their pre-trial costs, so the subgame equilibrium outcome is no entry.

Now suppose that $q m_{2}>c_{p 2}+k_{p 2}$. There are two relevant subcases.

Subcase 1. $F>\frac{c_{p 2}+c_{d 2}}{q m_{2}-c_{p 2}}$.

There does not exist a subgame equilibrium in which all meritless cases enter. If so, $D$ would offer $s_{2}=0$ as the settlement offer $q m_{2}-c_{p 2}$ would be accepted by all meritless cases and will cost him $\left(q m_{2}-c_{p 2}\right) N_{2}(1+F)$, which exceeds $\left(q m_{2}+c_{d 2}\right) N_{2}$, the payout at a trial to serious cases only. Meritless cases would withdraw after such a zero-offer, so their payoff from filing would be $-k_{p 2}$. Hence, they would not file, a contradiction.

There does not exist a subgame equilibrium in which no meritless cases file suits. If so, $D$ would settle with the serious cases by offering $s_{2}=q m_{2}-c_{p 2}$. But then any meritless case would want to enter because $q m_{2}-c_{p 2}-k_{p 2}>0$, a contradiction.

Therefore, in a subgame equilibrium, some meritless cases enter and some do not. This implies that a plaintiff with a meritless case must be indifferent between filing and not. Let $y$ denote the probability that $D$ offers $s_{2}=q m_{2}-c_{p 2}$; the probability of offering $s_{2}=0$ is $1-y$. From the indifference condition for a plaintiff with a meritless case,

$$
0=y\left(q m_{2}-c_{p 2}\right)+(1-y) 0-k_{p 2} \Rightarrow y=\frac{k_{p 2}}{q m_{2}-c_{p 2}}<1 .
$$

This implies that $D$ is indifferent between offering $s_{2}=q m_{2}-c_{p 2}$ to settle any case that enters and offering $s_{2}=0$, which results in a serious case going to trial. Let the expected number of meritless cases be $\hat{x} N_{2}$. Indifference of $D$ implies that

$$
\left(q m_{2}-c_{p 2}\right) N_{2}(1+\hat{x})=\left(q m_{2}+c_{d 2}\right) N_{2} \Rightarrow \hat{x}=\frac{c_{p 2}+c_{d 2}}{q m_{2}-c_{p 2}} .
$$

Subcase 2. $F<\frac{c_{p 2}+c_{d 2}}{q m_{2}-c_{p 2}}$. 
There does not exist a subgame equilibrium where meritless cases are indifferent between entering and not, because then, as in the analysis for Subcase 1, the expected number of meritless cases filed must be $\frac{c_{p 2}+c_{d 2}}{q m_{2}-c_{p 2}} N_{2}$, which exceeds the total number of meritless cases, $F N_{2}$. There does not exist a subgame equilibrium in which no meritless case enters, for the same reason as in Subcase 1. Therefore, $F N_{2}$ meritless cases suits are filed in equilibrium. Since $F<\frac{c_{p 2}+c_{d 2}}{q m_{2}-c_{p 2}}$, the best response of $D$ is to offer $q m_{2}-c_{p 2}$ to settle each lawsuit that is filed.

Proof of Lemma 3. Note that $q=\frac{1}{m_{2}}\left(\frac{c_{p 2}+c_{d 2}}{F}+c_{p 2}\right)$ is equivalent to $F=\frac{c_{p 2}+c_{d 2}}{q m_{2}-c_{p 2}}$, which means that $g$ is continuous for $q>\frac{c_{p 2}+k_{p 2}}{m_{2}}$. The payoff function is then directly implied by Lemma 2 . Next we show strict convexity of $g$ in the mixed equilibrium range.

$g^{\prime}(q)=\frac{m_{2} N_{2}}{\left(q m_{2}-c-p\right)^{2}}\left(k_{d 2}\left(c_{p 2}+c_{d 2}\right)-\left(q m_{2}-c_{p 2}\right)^{2}\right) \Rightarrow g^{\prime \prime}(q)=\frac{2 m_{2}^{2} k_{d 2} N_{2}\left(c_{p 2}+c_{d 2}\right)}{\left(q m_{2}-c_{p 2}\right)^{3}}>0$.

Proof of Proposition 7. Case 1. $\bar{\pi} m_{2}<c_{p 2}+k_{p 2}$. Here, regardless of the date-1 outcome, no date-2 plaintiffs enter. Then $D$ settles at date 1 .

Case 2. $\pi m_{2}<c_{p 2}+k_{p 2}<\bar{\pi} m_{2}$. These parameters imply that a plaintiff-win at date 1 attracts all serious date- 2 plaintiffs and some meritless ones who would not otherwise file lawsuits. This means that there are only costs to a date- 1 trial, so $D$ settles at date 1 .

Case 3. $\underline{\pi} m_{2}<c_{p 2}+k_{p 2}<\pi m_{2}$. In this parameter range, a defendant-win at date 1 causes all date-2 plaintiffs not to enter, while any other outcome would lead to their entry. By Lemma 3, the difference between $D$ 's payoffs from a date- 1 trial and a date- 1 settlement is,

$$
U^{T}-U^{S}=\pi g(\bar{\pi})-g(\pi)-\left(c_{p 1}+c_{d 1}\right)
$$

Case 4. $k_{p 2}+c_{p 2}<\underline{\pi} m_{2}$. Here, regardless of the date-1 outcome, all serious date-2 plaintiffs file suits as do some plaintiffs with meritless cases. The number of meritless cases filed depends on the date- 1 outcome. The difference in payoff for $D$ between a date- 1 trial and a date- 1 settlement is,

$$
U^{T}-U^{S}=\pi g(\bar{\pi})+(1-\pi) g(\underline{\pi})-g(\pi)-\left(c_{p 1}+c_{d 1}\right) .
$$

Proof of Proposition 8. If no date-2 suits are filed without commitment, commitment does not matter. When $D$ plays a mixed strategy at date 2 without commitment, her date- 2 payoff is $\left(-q m_{2}+\right.$ $\left.c_{p 2}-k_{d 2}\right) N_{2}\left(1+\frac{c_{p 2}+c_{d 2}}{q m_{2}-c_{p 2}}\right)$. If she commits to a trial, no meritless cases are filed, and her date- 2 
payoff is $\left(-q m_{2}-c_{d 2}-k_{d 2}\right) N_{2}$. If $k_{d 2}=0$, the two payoffs are equal. If $k_{d 2}>0$, the payoff under no commitment is worse because $k_{d 2}$ is applied to more plaintiffs (both serious and meritless ones). When $D$ plays a pure-strategy (settle) at date 2 , her date-2 payoff is $\left(-q m_{2}+c_{p 2}-k_{d 2}\right) N_{2}(1+F)$. If she commits to a trial, no meritless cases are filed, and her date-2 payoff is $\left(-q m_{2}-c_{d 2}-k_{d 2}\right) N_{2}$. The difference between these payoffs is $\left(c_{d 2}+c_{p 2}\right) N_{2}-\left(q m_{2}-c_{p 2}+k_{d 2}\right) N_{2} F$. Therefore, when $q<\frac{1}{m_{2}}\left(\frac{c_{p 2}+c_{d 2}}{F}+c_{p 2}-k_{d 2}\right)$, no commitment is better. 